Chapman University

Chapman University Digital Commons

Business Faculty Articles and Research

Business

4-8-2021

Do Large Gains Make Willing Sellers?

Dong Hong

Roger K. Loh

Mitch Warachka

Follow this and additional works at: https://digitalcommons.chapman.edu/business_articles

Part of the Other Business Commons, and the Real Estate Commons 


\section{Do Large Gains Make Willing Sellers?}

\section{Comments}

This article was originally published in Journal of Financial and Quantitative Analysis in 2021. http://doi.org/10.1017/S0022109021000193

Creative Commons License

(c) (i) (9)

This work is licensed under a Creative Commons Attribution-Noncommercial-Share Alike 4.0 License.

\section{Copyright}

The authors 

medium, provided the same Creative Commons licence is included and the original work is properly cited. The written permission of Cambridge University Press must be obtained for commercial re-use. doi:10.1017/S0022109021000193

\title{
Do Large Gains Make Willing Sellers?
}

\author{
Dong Hong \\ Independent \\ dhong1974@gmail.com \\ Roger K. Loh \\ Singapore Management University \\ rogerloh@smu.edu.sg \\ Mitch Warachka (iD \\ Chapman University \\ warachka@chapman.edu (corresponding author)
}

\section{Abstract}

Using unique real estate data that allow for accurately measured capital gains, we examine whether sell propensities depend on the magnitude of a seller's capital gain. We find that short-term sell propensities are flat over losses and increasing in gains. Consistent with their higher sell propensities, selling prices are lower for properties with larger gains. Large-sized short-term stock investments also have sell propensities that are flat over losses and increasing in gains, although the sell propensities of typical-sized short-term stock investments are V-shaped. Our findings provide empirical support for theories of realization utility.

\section{Introduction}

A large literature examines the impact of gains and losses on selling decisions. According to the disposition effect, positions with an unrealized gain are more likely to be sold than those with an unrealized loss (Odean (1998), Shefrin and Statman (1985), Weber and Camerer (1998), Barber, Lee, Liu, and Odean (2007)).

The usual explanation for the disposition effect is prospect theory (Kahneman and Tversky (1979)). However, Kaustia (2010) finds empirical evidence that prospect theory does not explain the disposition effect. More formally, Barberis

We thank an anonymous referee, Jennifer Conrad (the editor), and Peter Kelly (a referee) for their valuable comments. We also thank Tom Aabo, Sumit Agarwal, Brad Barber, Jiangze Bian, Hyun-Soo Choi, Phil Dybvig, Bing Han, David Hirshleifer, Harrison Hong, Maggie Hu, Roni Michaely, Milena Petrova, Todd Sinai, Joshua Spizman, Avanidhar Subrahmanyam, Wei Xiong, as well as seminar participants at Claremont McKenna College, Loyola Marymount University, Singapore Management University, and Tsinghua University for their helpful comments. We acknowledge financial support from the Sim Kee Boon Institute for Financial Economics. 
and Xiong (2009) demonstrate that prospect theory preferences defined over annual gains and losses do not actually predict the disposition effect. Instead, it is preferences defined over realized gains and losses that more reliably predict the disposition effect. Barberis and Xiong (2012) describe the role of realized gains and realized losses on investor behavior by introducing realization utility. In their theory, investors obtain utility from realizing a gain and disutility from realizing a loss, with the realization of a larger gain yielding greater utility. This dependence of utility on the magnitude of a seller's gain leads to the appearance of the disposition effect. With the discounting of future losses and the disutility of losses only occurring upon realization, investors delay selling positions with a loss until forced to by a liquidity shock. Conversely, gains are quickly realized to experience a burst of utility. Frydman, Barberis, Camerer, Bossaerts, and Rangel (2014) provide experimental evidence that investors exhibit neural activity consistent with realization utility, and Kelly (2018) provides supporting evidence from the trades of company insiders.

Empirical tests of the disposition effect typically compute the aggregate sell propensity of all gains without conditioning on the magnitude of gains and losses (e.g., Odean (1998)). These tests cannot determine whether the propensity to sell depends on having a gain (vs. a loss) or the gain's magnitude. Consequently, these tests cannot identify the underlying channel that explains why positions with a gain have a higher sell propensity. Ben-David and Hirshleifer (2012) argue that the disposition effect implies a discontinuity in the sell propensity due to the important distinction between gains and losses that predicts positions with a small gain are more likely to be sold than those with a small loss. However, Ben-David and Hirshleifer (2012) find no difference in the sell propensities of small gains vs. small losses. Therefore, these authors conclude that stock investors do not exhibit the disposition effect.

One disadvantage of using selling activity in the stock market to test the disposition effect is that investors can buy and sell shares at different prices in different quantities at different points in time. This flexibility confounds reference prices, which typically become the weighted averages of several stock transactions. More importantly, individual investor data sets contain stock investments that are typically less than $\$ 10,000$. Whether these amounts are sufficiently large to have a meaningful impact on consumption, and consequently offer meaningful conclusions about investor behavior, is unclear. However, real estate transactions are sufficiently large to impact consumption, especially for households that are credit constrained (Gan (2010), Agarwal and Qian (2017), and Vinson (2018)). In general, Case, Quigley, and Shiller (2013) find that real estate prices impact household consumption more than stock prices. ${ }^{1}$

In this article, we use real estate data to examine the impact of a capital gain's magnitude on the decision to sell. Barberis and Xiong (2012) argue that real estate transactions, which are large and infrequent, likely constitute investing episodes with salient reference prices and distinct mental accounts. Furthermore, real estate transactions involve indivisible assets that cannot be partially

\footnotetext{
${ }^{1}$ Ghysels, Plazzi, Valkanov, and Torous (2013) also emphasize the importance of residential real estate as an asset class since its aggregate value is comparable to the stock market's.
} 
liquidated, thereby preserving the salience of historical reference prices. Although the importance and size of real estate transactions may incentivize investors to avoid making suboptimal decisions, residential real estate transactions might be associated with more emotional attachment and hence greater behavioral biases. In other markets, O'Connell and Teo (2009) find that the disposition effect does not affect institutional investors in the currency market and Cici (2012) reports that experience mitigates the disposition effect among institutional investors in the equity market. Ultimately, whether the magnitude of capital gains affects selling decisions in the residential real estate market is an empirical question.

In the United States, it is difficult to accurately measure unrealized gains in the residential real estate market because individual properties are often unique and trade in an illiquid market. To overcome this problem, we study more than 280,000 transactions in Singapore's condominium market, which is comprised standardized units within multi-unit condominium projects. This standardization allows unitlevel market prices, hence unrealized gains, to be estimated using the average selling price per square feet (PSF) of other transactions in the same condominium project. Because regulations prohibit extensive remodeling, apartment units are largely homogeneous within a condominium project except for floor level and size. In our data, a simple hedonic model with floor level and size explains nearly $90 \%$ of the variation in unit-level transaction prices within a typical condominium project. Moreover, while residential property sales in the United States are often influenced by employment opportunities, property sales in Singapore are less confounded by the variation within the city state's labor market.

Our quarterly data allow us to estimate the full schedule of unrealized gains and losses for the entire cross-section of condominium units. For each quarterly cross-section, we determine the sell propensity for units with different gains or losses. Figure 1 illustrates the main testable hypotheses in our paper. Specifically, Graph A in Figure 1 illustrates the sell propensities implied by Odean (1998) that has units with gains, regardless of their magnitude, being more likely to be sold than units with losses. Graph B illustrates the sell propensities predicted by Barberis and Xiong's (2012) realization utility with heterogeneous investors that has sell propensities increasing as gains become larger, and flat sell propensities over losses that are only realized because of exogenous shocks that force liquidation. Graph $\mathrm{C}$ illustrates the sell propensities predicted by Ingersoll and Jin's (2013) realization utility that allows for a negative slope over losses for investors who realize a loss in order to reset their reference price at a lower level. According to Ben-David and Hirshleifer's (2012) study of stock transactions, the V-shape in Graph $\mathrm{C}$ of Figure 1 is also consistent with belief revision. Belief revision posits that sales result from speculative investors being more likely to revise their beliefs after market prices move farther away from the original purchase price.

In general, we find that units with a gain are almost twice as likely to be sold as units with a loss. Importantly, sell propensities increase with the magnitude of gains and are mostly flat over losses. This finding provides empirical support for realization utility. Panel estimations confirm the positive unit-level relation between 
FIGURE 1

Sell Propensities

Figure 1 illustrates the sell propensities based on the predictions of the disposition effect in Odean (1998) (Graph A), realization utility in Barberis and Xiong (2012) with heterogeneous investors (Graph B), belief revision in Ben-David and Hirshleifer (2012) or extended realization utility in Ingersoll and Jin (2013) (Graph C), and financing constraints in Stein (1995) (Graph D).

Graph A. Disposition Effect in Odean

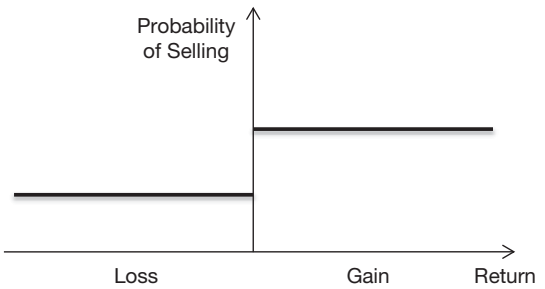

Graph C. Belief Revision in Ben-David and Hirshleifer, or Extended Realization Utility in Ingersoll and Jin

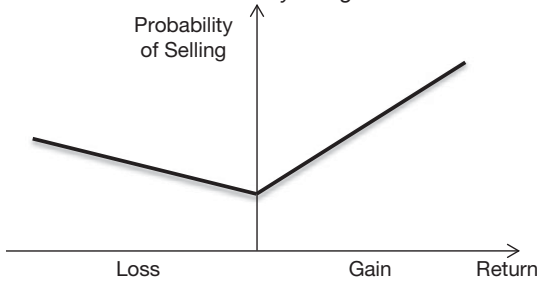

Graph B. Realization Utility in Barberis and Xiong with Heterogeneous Investors

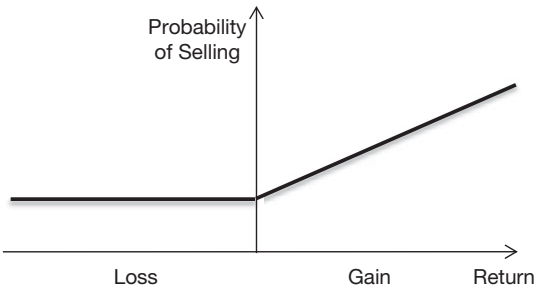

Graph D. Financing Constraints in Stein

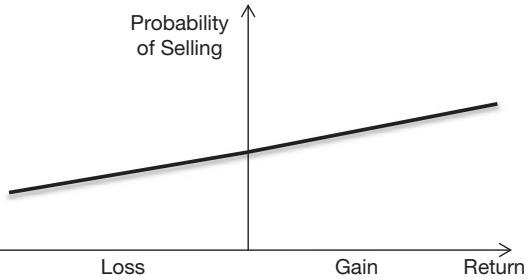

the magnitude of gains and sell propensities after controlling for unit-level and market-level characteristics, including quarter and condominium project fixed effects.

Besides studying sell propensities, real estate transactions enable us to study the response of selling prices to gain magnitudes. Theoretical models of realization utility have transactions occurring instantaneously at threshold prices that sellers determine ex ante. However, transaction prices in real estate markets are endogenous as sellers choose to accept an offer from potential buyers. Hayunga and Munneke (2019) highlight the role of imperfect competition in the real estate market as bargaining exerts a significant impact on transaction prices. Our conjecture is that sellers with a large unrealized capital gain are more willing to accept price concessions (accept an offer below a property's market price). ${ }^{2}$ We find that units with a larger gain sell for a lower price than otherwise comparable units. Although not a clear prediction of realization utility, this result offers an interesting potential implication of realization utility — higher sell propensities for positions with a larger gain could be facilitated by price concessions.

We carefully examine several alternative hypotheses. In the stock market, informed investors are predicted to sell a position once their positive private information has been incorporated into the stock's price and produced a gain.

\footnotetext{
${ }^{2} \mathrm{~A}$ price concession is unlikely if the seller only has a small gain since accepting a lower offer endangers this small gain.
} 
A large loss might also lead investors to revise their beliefs and sell the position. Ben-David and Hirshleifer (2012) find that sell propensities in the stock market increase with the magnitude of a position's gain and, less dramatically, with the absolute magnitude of a position's loss. However, unit-level property prices in Singapore are less sensitive to private unit-level information that is subject to revision. Indeed, property price fluctuations are highly correlated due to the city state's small size and extensive public transportation. Because a V-shape is also consistent with the realization utility model in Ingersoll and Jin (2013), any evidence of a V-shape in our real estate data is likely to be more consistent with realization utility. However, our results provide no evidence that sell propensities are increasing with the magnitude of real estate losses. The lack of a V-shape indicates that sell propensities in the real estate market are more consistent with Barberis and Xiong's (2012) realization utility than with Ingersoll and Jin's (2013) model or with Ben-David and Hirshleifer's (2012) belief revision. ${ }^{3}$

In addition, Stein (1995) proposes that financing constraints explain the higher sell propensities of properties with a gain since real estate represents a large fraction of wealth that is financed with debt. Thus, higher property prices increase the equity available to finance upgrades. Financing constraints predict that sell propensities increase linearly with the magnitude of gains, as in Graph D of Figure 1. However, we find mixed evidence that sell propensities are upward sloping over losses. Our results supporting realization utility are also robust to the inclusion of several unit-level and market-level proxies for financing constraints.

Our study is not the first to examine gains in the real estate market. Genesove and Mayer (2001) report that condominium owners with a loss in Boston list their units for sale at higher prices. However, their study cannot explicitly test the predictions of realization utility or the disposition effect because listings data are insufficient to estimate sell propensities. ${ }^{4}$ Estimating gains in Boston is also complicated by unobservable property attributes and renovations that affect a unit's market price. In contrast, our data allow the return since purchase to be accurately estimated along with sell propensities that condition on these return magnitudes.

Barberis and Xiong (2012) argue that housing transactions with their salient reference prices are ideal for empirical tests of realization utility. We show that the predictions of realization utility are also supported in stock investment transactions that have similar attributes as real estate. Specifically, using the discount brokerage data set in Barber and Odean (2000), we find that large-sized stock transactions have short-term sell propensities similar to those from our real estate data set: flat over losses and upward sloping in gains. We also find that the slope over losses gets increasingly flat as size or relative size increases, which is consistent with it being

\footnotetext{
${ }^{3}$ Another justification for the appearance of realization utility is mean reversion. However, property prices in Singapore do not exhibit negative autocorrelation. Instead, the autocorrelation in property prices is positive over a one-quarter horizon and insignificant over an annual horizon. Furthermore, in a real estate market where expected returns are highly correlated across individual properties, the realization of a gain is difficult to attribute to mean reversion if the majority of sellers reinvest their sales proceeds in another property.

${ }^{4}$ In addition, listings data may exclude properties with a loss since the listing of a property signals the owner's intention to sell. Realization utility and the disposition effect both predict that properties with a loss are less likely to be sold, and therefore are less likely to be listed.
} 
more difficult to admit a mistake when size gets larger. However, for typical shortterm stock transactions, we confirm Ben-David and Hirshleifer's (2012) finding that sell propensities exhibit a V-shaped pattern centered at a zero gain. While Ben-David and Hirshleifer (2012) conclude this V-shaped pattern supports the revision of beliefs by speculative traders, Ingersoll and Jin (2013) demonstrate that this pattern is also consistent with a realization utility theory that has referencedependent preferences. Hence, for small-sized stock transactions, their V-shaped pattern can be consistent with either explanation. However, in our study of real estate transactions, realization utility is more applicable than belief revision since private information subject to revision is minimal. Nevertheless, our support for realization utility extends beyond the real estate market to selling behavior in the stock market for sufficiently large-sized stock transactions.

The remainder of this article begins with a detailed description of our hypotheses in Section II. Section III then describes our data, while Section IV presents our empirical results. Alternative explanations and other tests are discussed in Section V, followed by our conclusion in Section VI.

\section{Sell Propensity Hypotheses}

This section describes the sell propensity patterns predicted by various theories of seller behavior.

\section{A. Flat With a Step Up Over Gains}

The simplest prediction in the disposition effect literature is that investors are more willing to sell a position at a gain than a position at a loss. In other words, sell propensities are flat over losses and then step up when returns switch from negative to positive.

In defining the ratio $\frac{\text { PGR }}{\text { PLR }}$ (proportion of gains realized over the proportion of losses realized), Odean (1998) implicitly assumes this step-up pattern for sell propensities, as we illustrate in Graph A of Figure 1. Based on this pattern, BenDavid and Hirshleifer (2012) test whether sell propensities are higher for small gains compared to small losses but do not find empirical support for the existence of a discontinuity at a zero gain.

\section{B. Flat Over Losses and Upward Sloping Over Gains}

In the realization utility model of Barberis and Xiong (2012), investors sell when an asset's return hits a specific threshold. This threshold is defined relative to the purchase price (plus any transaction costs). Hence, sell propensities are low and flat over losses and then jump once the return hits the threshold. The flat selling propensities over losses stem from an assumed Poisson process that forces liquidation due to a liquidity shock. Sell propensities are undefined for large returns because investors sell the asset before a large return is obtained. In particular, with a positive discount rate, the tradeoff between realizing a small gain immediately vs. realizing a (potentially) larger future gain leads investors to realize small gains.

Although not modeled explicitly by Barberis and Xiong (2012), heterogeneity regarding the sell thresholds of investors allows large gains to exist. For example, 
investors could have heterogeneous prospect theory preferences (degrees of loss aversion) or heterogeneous discount rates for discounting potentially larger future gains. With heterogeneous investors, sell propensities are positively related to the magnitude of gains. Specifically, as the return since purchase increases, a larger fraction of investors (those with a lower selling threshold) have already sold, resulting in a smaller fraction of investors who continue to hold assets with such a large return. In other words, as the magnitude of an unrealized gain increases, there are fewer properties remaining to sell at that magnitude, which implies that a sale transaction at that higher-return magnitude results in a higher sell propensity. This hypothesized selling pattern is illustrated by Graph B in Figure 1.

\section{V-Shaped Slope Over Losses and Gains}

Graph C in Figure 1 illustrates the V-shaped sell propensity pattern that BenDavid and Hirshleifer (2012) find in short-term stock investments. The authors conclude that this selling pattern is consistent with belief revision that arises from a speculative motive for trading. Small gains and losses provide little reason for an investor to revise their beliefs, implying a low-sell propensity for gains and losses near zero. In contrast, when information arrival leads to large gains or losses, investors are more likely to revise their beliefs. Specifically, large gains or losses motivate investors to assess whether the market has incorporated their private information into the market price (sell and realize a gain) or whether their original belief was incorrect (sell and realize a loss). The slope is less steep on the loss side and Ben-David and Hirshleifer (2012) explain that this could be due to overconfident investors being more ready to sell winners.

Interestingly, a V-shaped sell propensity is also consistent with the realization utility theory of Ingersoll and Jin (2013) that allows realization utility to have an $\mathrm{S}$-shape as a result of reference-dependent preferences. This extension generates 2 selling thresholds; one in the gain region and another in the loss region, which is a little further from the reference point. Intuitively, an investor may liquidate a large loss and reset the reference price at a lower level to allow for a utility gain (due to the the S-shaped function) on the reinvestment. Hence, the V-shaped sell propensities in Graph $\mathrm{C}$ of Figure 1 are not an unique implication of belief revision, but can also arise from realization utility.

Our main empirical tests use real estate transactions. These transactions are executed in a market driven more by a systematic market factor than by idiosyncratic unit-level information. Hence, belief revision is less likely to influence selling behavior. Consequently, any evidence of a V-shape for sell propensities in our real estate data is more likely support for Ingersoll and Jin (2013). In a later section, we also examine the stock trading data set used by Ben-David and Hirshleifer (2012). Evidence of a V-shaped pattern in a stock trading data set can be interpreted as being consistent with either belief revision or the extended version of realization utility in Ingersoll and Jin (2013).

\section{Upward Sloping Over Both Losses and Gains}

Stein (1995) proposes an alternative explanation based on financing constraints for the appearance of the disposition effect in the real estate market. 
As real estate represents a large fraction of household wealth that is typically debtfinanced, a decline in property prices tightens financing constraints by reducing the sale proceeds available to purchase an upgrade (more expensive property). This channel applies to corporate lending activity as Gan (2007) documents tighter financing constraints following a decline in property prices.

In our residential real estate setting, the financing constraint hypothesis implies that sell propensities increase over losses and gains as an increase in a seller's property price increases the equity available for their next property purchase. Graph D in Figure 1 illustrates the upward sloping sell propensities associated with the financing constraints hypothesis.

\section{Data}

Our data are from Singapore's private condominium market. A typical condominium project in Singapore consists of 200-300 condominium units in high-rise buildings. In our sample, the average building height is 15 floors and the average size of a unit is approximately 1,300 square feet. Besides a unit's size and floor level, units are largely homogeneous within the same project. For example, walls between rooms typically cannot be removed, and windows and doors that alter the unit's original design cannot be installed. Therefore, compared to residential real estate in the United States, unobservable attributes exert less impact on unit-level PSF prices in Singapore.

Sale transactions involving condominium units are reported the Urban Redevelopment Authority (URA), a Singapore government agency. Our sale transactions data are from URA's Real Estate Information System (REALIS). This database is also used by Giglio, Maggiori, and Stroebel (2015) in their study of long-term discount rates.

URA lists the details of each transaction on a website, usually within 2 weeks of a transaction. As a result, property investors can use observed transaction prices within their condominium project to infer their unit's market price, and compute its associated unrealized gain or unrealized loss. The absence of capital gain taxes in Singapore mitigates the need to examine after-tax gains.

The URA data record the transaction date, condominium project name, transaction price, unit size, street address, floor level, and unit number. We do not observe the identity of the buyer or seller. Our URA data begin in 1995 and ends in 2012. After excluding condominium projects with less than 50 transactions during this sample period, a total of 282,920 transactions remain. For certain units, we identify a size discrepancy on different transaction dates. After excluding units whose size discrepancy exceeds $2 \%$, our sample contains 277,856 transactions involving 1,104 condominium projects and 185,383 unique units.

Unlike studies of the disposition effect that have to estimate historical purchase prices (Grinblatt and Han (2005)), our data provide a nearly complete set of historical purchase prices to serve as reference prices. Transaction costs are relatively low in Singapore's real estate market, with agents earning about a $1 \%$ fee from sellers. The relatively high liquidity and low transaction costs in Singapore's real estate market makes the immediate realization of gains more likely, which is 
ideal for testing our null hypothesis that the magnitude of an investor's gain is irrelevant to their sell propensity.

\section{A. Estimation of Return Since Purchase}

A unit's return since purchase is defined as the percentage change in the unit's price PSF since its purchase. To compute this return, the unit's most recent purchase price and its current market price are needed.

The unit's most recent purchase price is extracted from the URA data, which begins in 1995. Because property purchases before 1995 are not observed, we start our estimation procedure in 1998 to ensure that 3 years of past transactions are available. Table 1 reports the number of units for which past purchase prices are available each quarter from 1998 to 2012. The available number of units increases over time as more units are sold and enter the URA records. We also compare the number of available units to the entire stock of condominium units in Singapore, and report the relevant sample coverage estimates in Table $1 .{ }^{5}$ By the end of 2012, our sample coverage is nearly $83 \%$. This coverage does not reach $100 \%$, because some units are purchased before 1995 and are not sold during our sample period. These units are less relevant for our tests since their long holding period is likely inconsistent with an investment motive. To identify real estate transactions that are most likely to have an investment motive, our regressions focus on units whose holding period is 3 years or less (i.e., units for which the most recent sale is less than 3 years ago), or units whose absolute return since purchase is within $20 \%$ of their purchase price (i.e., unsold units with large returns are less likely to be held for investment motives).

Table 1 reports an upward trend in Singapore property prices that coincides with considerable price volatility. In Han (2010), price uncertainty in the real estate market does not necessarily reduce the demand for property because of incentives to hedge against price increases. These incentives are particularly strong in Singapore due to the high cross-correlation in property prices, limited availability of land, and population growth (Han (2013)).

According to Table 1, the average price of a residential condominium unit in a typical quarter is $\mathrm{S} \$ 1,046,226$, which is equivalent to $\$ 666,411$ using the average exchange rate of 1.57 SGD per USD during the 1998-2012 period. The average price PSF equals S\$886 (equivalent to $\$ 564$ ). Figure 2 plots the average PSF and transaction volume each quarter from 1995 to 2012 . The 0.684 correlation between the average PSF and the transaction volume highlights the well-known positive price-volume relation in the real estate market.

To measure each unit's percentage gain (i.e., return) since purchase, we need its current estimated price. To obtain this, we estimate a simple hedonic pricing model within each condominium project by regressing the average quarterly PSF transaction prices within the condominium project on quarterly dummies. This method controls for condominium project-specific characteristics such as location, age, lease-period remaining, facilities, and quality. Neighborhood characteristics

\footnotetext{
${ }^{5}$ We estimate the total housing stock using the website https://www.propertyguru.com.sg/ that records the total number of units in each condominium project.
} 


\section{Quarterly Inventory of Units and Summary Statistics}

Table 1 reports summary statistics for the historical inventory of condominium units in Singapore each quarter from 1998 to 2012 according to URA data which start in 1995. A unit is included only if it has already appeared once earlier so that its return since the most recent purchase can be estimated. Statistics regarding the historical sale price, square footage (size), price per square feet (PSF), years held (HOLDING_PERIOD), and number of condominiums projects (condos) are included. Sample coverage is estimated by comparing the units in our sample with the total number of units in condominiums using the website https:// www.propertyguru.com.sg/. The second set of columns pertain to descriptive statistics for sale transactions in the Urban Redevelopment Authority (URA) data. The average SGD exchange rate is 1.57 SGD per USD during the 1998-2012 period.

Historical Inventory

Sales

Avg. Avg. Avg. Avg. No. No. Housing Sample Avg. Avg. No.

Date SGD Price SIZE SGD PSF yrs Held of Condos of Units Inventory Coverage SGD Price SGD PSF of Units

$03 / 31 / 1998 \$ 1,051,7271,368 \quad \$ 752$

06/30/1998 $\$ 1,032,6031,366 \quad \$ 741$ $09 / 30 / 1998 \$ 1,019,2671,367 \quad \$ 731$

$12 / 31 / 1998 \quad \$ 981,1211,369 \$ 701$

$03 / 31 / 1999 \$ 958,9071,368 \quad \$ 689$

06/30/1999 \$939,276 1,370 \$676

$09 / 30 / 1999 \$ 937,9451,372 \$ 675$

$12 / 31 / 1999 \$ 941,5321,372 \quad \$ 678$

$03 / 31 / 2000 \$ 938,4531,376 \quad \$ 675$

$06 / 30 / 2000 \quad \$ 935,3701,378 \quad \$ 672$

09/30/2000 \$941,905 1,380 \$675

$12 / 31 / 2000 \quad \$ 935,6371,380 \quad \$ 670$

$03 / 31 / 2001 \quad \$ 931,1341,377 \quad \$ 669$

$06 / 30 / 2001 \quad \$ 927,3971,381 \quad \$ 664$

09/30/2001 \$916,256 1,377 \$658

$12 / 31 / 2001 \quad \$ 916,8511,372 \quad \$ 663$

03/31/2002 \$898,802 1,368 \$652

06/30/2002 \$895,175 1,367 \$650

09/30/2002 \$885,027 1,364 \$644

$12 / 31 / 2002 \quad \$ 883,8831,364 \quad \$ 644$

$03 / 31 / 2003 \quad \$ 883,9581,366 \quad \$ 642$

06/30/2003 \$876,354 1,360 \$640

$09 / 30 / 2003 \$ 869,9641,360 \$ 636$

$12 / 31 / 2003 \quad \$ 861,7911,360 \quad \$ 630$

03/31/2004 \$870,933 1,364 \$634

$06 / 30 / 2004 \$ 868,2761,362 \$ 634$

$09 / 30 / 2004 \$ 866,531 \quad 1,358 \quad \$ 635$

$12 / 31 / 2004 \$ 861,4851,362 \quad \$ 629$

$03 / 31 / 2005 \quad \$ 865,4841,367 \quad \$ 629$

06/30/2005 \$868,187 1,367 \$632

09/30/2005 \$867,566 1,367 \$631

$12 / 31 / 2005 \quad \$ 874,0981,366 \quad \$ 638$

03/31/2006 \$878,802 1,367 \$640

06/30/2006 \$886,403 1,367 \$644

09/30/2006 \$896,503 1,368 \$648

$12 / 31 / 2006 \quad \$ 920,5111,370 \quad \$ 661$

03/31/2007 \$946,744 1,370 \$678

06/30/2007 \$990,053 1,369 \$706

09/30/2007 \$1,032,989 1,365 \$738

$12 / 31 / 2007 \$ 1,034,1151,357 \quad \$ 743$

$03 / 31 / 2008 \$ 1,044,9781,359 \$ 750$

06/30/2008 \$1,046,241 1,362 \$749

09/30/2008 \$1,026,189 1,351 \$747

$12 / 31 / 2008 \$ 1,023,0651,355 \$ 743$

03/31/2009 \$1,038,205 1,356 \$751

06/30/2009 \$1,063,930 1,358 \$767

09/30/2009 \$1,087,631 1,354 \$786

$12 / 31 / 2009 \$ 1,106,0061,352 \$ 804$

$03 / 31 / 2010 \$ 1,122,747 \quad 1,348 \quad \$ 821$

$06 / 30 / 2010 \$ 1,148,1001,345 \$ 844$

$09 / 30 / 2010 \$ 1,149,1751,332 \$ 856$

$12 / 31 / 2010 \$ 1,167,7661,330 \quad \$ 873$

$03 / 31 / 2011 \$ 1,178,6411,322 \$ 889$

$06 / 30 / 2011 \$ 1,194,1081,315$

09/30/2011 \$1,199,482 1,309 \$918

$12 / 31 / 2011 \$ 1,194,5631,300 \$ 924$

$03 / 31 / 2012 \$ 1,187,4651,292 \$ 927$

06/30/2012 \$1,202,069 1,284 \$945

09/30/2012 \$1,215,034 1,282 \$955

$12 / 31 / 2012 \$ 1,217,0821,271$ \$966

Overall \$991,6911,355 \$726
1.71296

$1.85 \quad 323$

$2.02 \quad 340$

$2.02 \quad 364$

$2.07 \quad 393$

$2.01 \quad 412$

$2.08 \quad 407$

$2.24 \quad 399$

$2.39 \quad 391$

252385

$2.64 \quad 390$

$2.81 \quad 370$

$3.00 \quad 370$

$3.13 \quad 392$

$3.24 \quad 384$

3.39

3.32

3.43

3.52

3.71

3.90

4.01

4.12

4.26

4.44

4.53

4.66

4.76

4.89

4.95

4.98

5.02

5.10

5.11

5.13

5.06

5.00

4.76

4.69

4.80

4.94

5.09

5.22

5.43

5.56

5.48

5.28

5.32

5.28

5.19

5.19

5.18

5.19

5.16

5.21

5.26

5.34

5.32

5.38

5.35
$26,949 \quad 77,32$

$28,283 \quad 79,855 \quad 35.42 \%$

$31,870 \quad 82,611 \quad 38.58 \%$

$35,630 \quad 85,739 \quad 41.56 \%$

$40,685 \quad 88,023 \quad 46.22 \%$

$42,990 \quad 88,562 \quad 48.54 \%$

$44,035 \quad 88,328$

$44,789 \quad 88,414$

$45,686 \quad 90,077$

47,059

93,036

$49.85 \% \quad \$ 1,069,815$

$50.66 \% \quad \$ 1,004,589$

$\begin{array}{llll}47,638 & 91,292 & 51.24 \% & \$ 988,088\end{array}$

$49,267 \quad 94,011 \quad 52.41 \% \quad \$ 828,095$

$50,081 \quad 93,728 \quad 53.43 \% \quad \$ 756,361$

$52,834 \quad 99,891 \quad 52.89 \%$

$\$ 766,025$

$59,460 \quad 105,266 \quad 56.49 \%$

$60,776 \quad 106,287 \quad 57.18 \%$

$61,994 \quad 105,461 \quad 58.78 \%$

$\$ 721,795$

$\$ 813,313$

$\$ 774,995$

$61,918 \quad 105,266 \quad 58.82 \%$

$62,006 \quad 105,237 \quad 58.92 \%$

$66,085 \quad 112,050 \quad 58.98 \%$

$67,404 \quad 111,940 \quad 60.21 \%$

$66,865 \quad 110,306 \quad 60.62 \%$

$68,542 \quad 111,291 \quad 61.59 \%$

$71,306 \quad 115,439 \quad 61.77 \%$

$73,874 \quad 118,957 \quad 62.10 \%$

$74,599 \quad 119,600 \quad 62.37 \%$

$75,506 \quad 122,090 \quad 61.85 \%$

$79,349 \quad 126,513 \quad 62.72 \%$

$83,375 \quad 129,694$

$85,735130,597$

$88,695 \quad 134,348$

$64.29 \%$

$\$ 787,355$

$\$ 752,932$

$\$ 708,454$

$\$ 740,709$

$\$ 739,946$

$\$ 794,985$

$\$ 799,313$

$\$ 771,742$

$\$ 860,473$

$\$ 826,040$

$\$ 853,361$

$\$ 891,882$

$91,629 \quad 135,723$

$94,307 \quad 137,350$

$65.65 \% \quad \$ 1,024,978$

$66.02 \% \quad \$ 997,848$

$67.51 \% \quad \$ 1,127,044$

$-68.66 \% \quad \$ 1,225,009$

$104,355 \quad 144,653$

$110,232 \quad 148,649$

\$1,283,071

$\begin{array}{ll}72.14 \% & \$ 1,396,710 \\ 74.16 \% & \$ 1,403,768\end{array}$

$76.09 \% \quad \$ 1,626,858$

$113,144 \quad 148,692$

$\begin{array}{ll}110,574 & 144,901 \\ 109,491 & 143,833\end{array}$

$110,234 \quad 144,428$

$76.31 \% \$ 1,624,330$

$76.12 \% \quad \$ 1,289,644$

$76.33 \% \quad \$ 1,300,444$

$109,173 \quad 142,509$

$103,747 \quad 137,774$

$116,614 \quad 154,979$

$76.61 \% \quad \$ 1,224,799$

$75.30 \% \quad \$ 1,056,463$

$75.25 \% \quad \$ 841,425$

$76.50 \% \quad \$ 1,135,040$

$124,997 \quad 163,397$

$130,665 \quad 167,945$

$132,844 \quad 171,235$

$136,638 \quad 173,590$

$141,466 \quad 177,475$

$143,285 \quad 179,633$

$146,318 \quad 182,752$

$149,464 \quad 190,918$

$153,371 \quad 191,472$

$153,745 \quad 192,440$

$156,113 \quad 194,138$

$161,714 \quad 200,706$

$169,696210,450$

$172,968 \quad 212,817$

$168,021202,519$

$89,693 \quad 131,913$

$\$ 646715$

$\$ 579 \quad 1,653$

$\$ 520 \quad 1,404$

$\$ 469 \quad 3,628$

$\$ 530 \quad 3,389$

$\$ 589 \quad 5,694$

$\$ 676 \quad 3,450$

$\$ 747 \quad 2,169$

$\$ 714 \quad 1,960$

$\$ 685 \quad 1,949$

$\$ 720 \quad 2,379$

$\$ 685 \quad 1,712$

$\$ 589 \quad 1,439$

$\$ 595 \quad 1,769$

$\$ 572 \quad 2,456$

$\$ 567 \quad 1,647$

$\$ 558 \quad 5,385$

$\$ 605 \quad 2,665$

$\$ 583 \quad 3,138$

$\$ 574 \quad 1,971$

$\$ 547 \quad 857$

$\$ 580 \quad 1,738$

$\$ 565 \quad 2,845$

$\$ 546 \quad 1,574$

$\$ 563 \quad 1,686$

$\$ 574 \quad 2,020$

$\$ 570 \quad 1,970$

$\$ 648 \quad 2,543$

$\$ 596 \quad 1,726$

$\$ 634 \quad 3,092$

$\$ 624 \quad 3,659$

$\$ 741 \quad 3,568$

$\$ 677 \quad 3,028$

$\$ 726 \quad 4,258$

$\$ 804 \quad 4,266$

$\$ 866 \quad 6,682$

$\$ 920 \quad 6,631$

$\$ 967 \quad 11,437$

$\$ 1,183 \quad 8,327$

3,877

2,386

2,875

3,595

1,375

2,860

7,733

10,586

5,638

7,561

8,517

7,043

7,292

6,074

8,026 


\section{FIGURE 2}

\section{Average Sale PSF and Transaction Volume}

Figure 2 illustrates the price and volume dynamics in Singapore's real estate market during our sample period. The marketlevel SGD price per square feet (PSF) of sale transactions and the corresponding transaction volume are reported every quarter. The market-level PSF is computed by first averaging the PSF of all sale transactions within each condominium project, and then averaging these condominium project-level averages across all condominium projects.

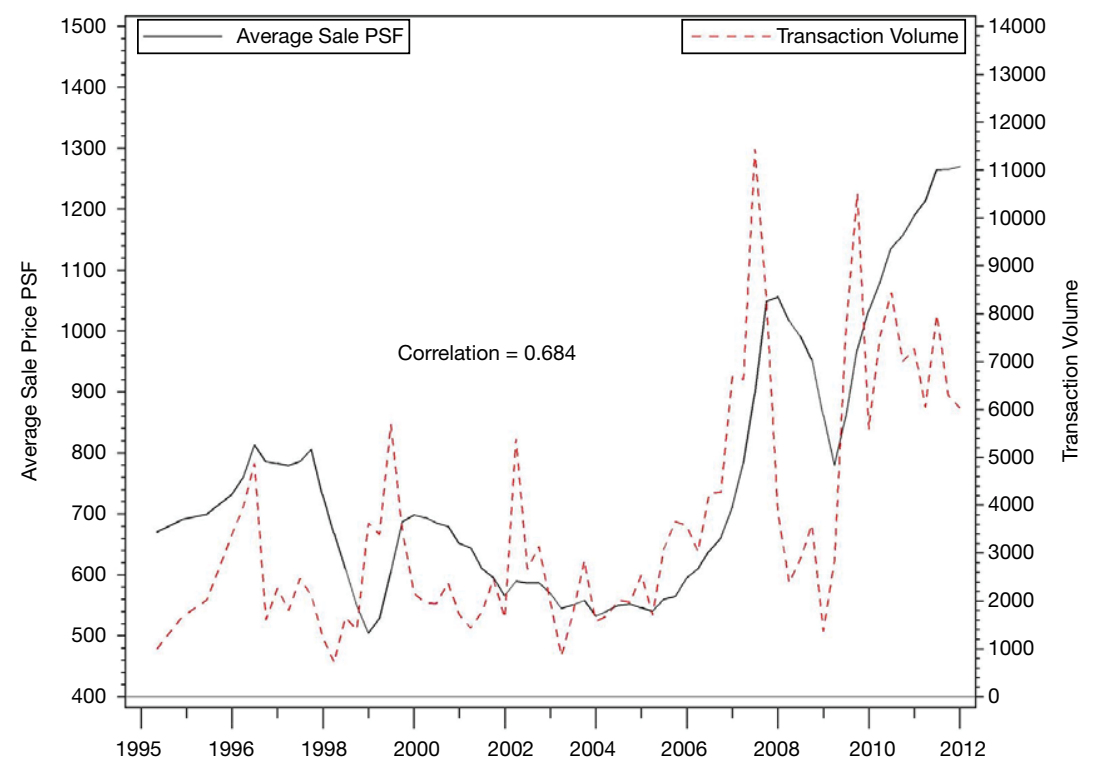

are also accounted for by this methodology. ${ }^{6}$ Condominium projects that average fewer than 2 sale transactions per quarter are excluded from the pricing model.

We also estimate an extended pricing model that contains each unit's log size (square feet) and floor level to supplement the quarterly dummies

(1) $\left.\mathrm{PSF}_{i, t}=\sum_{t=\mathrm{Q} 11995}^{\mathrm{Q} 42012} \beta_{t} \mathrm{QUARTER}_{t}+\beta_{\mathrm{s}} \mathrm{LOG}_{\mathrm{SIZE}}\right)_{i}+\beta_{\mathrm{f}} \mathrm{FLOOR} \mathrm{LEVEL}_{i}+\varepsilon_{i, t}$.

The coefficients for both models are estimated within the entire 1995-2012 sample period using all units indexed by $i$ having sale transactions in quarter $t$ in the same condominium project. We then report the distribution of the coefficients across the condominium projects. Table 2 reports an average adjusted $R^{2}$ of $74 \%$ for the simple pricing model that contains only quarterly dummy variables. Hence, a condominium project's average quarterly PSF explains nearly threequarters of the price variation across units within the same condominium project.

The inclusion of size and floor characteristics in the extended pricing model increases the average $R^{2}$ to $88 \%$. According to Table 2 , the average $\beta_{\mathrm{s}}$ coefficient is

\footnotetext{
${ }^{6}$ Agarwal, Rengarajan, Sing, and Yang (2016) find that school districts in Singapore impact condominium prices, although their effects are economically small compared to the gains in our study.
} 
TABLE 2

Price Correlation Within Condominiums Projects

\begin{tabular}{|c|c|c|}
\hline Number of condo projects & 1,014 & 1,014 \\
\hline $\begin{array}{l}\text { Quarterly indicator variables } \\
\text { Average size coefficient } \\
\text { Average size } t \text {-statistic }\end{array}$ & Yes & $\begin{array}{l}\text { Yes } \\
-0.13 \\
(8.90)\end{array}$ \\
\hline $\begin{array}{l}\text { Average floor level coefficient } \\
\text { Average floor level } t \text {-statistic }\end{array}$ & & $\begin{array}{r}7.15 \\
(6.13)\end{array}$ \\
\hline $\begin{array}{l}\text { Adj. } R^{2} \text { percentiles } \\
1 \% \\
10 \% \\
25 \% \\
\text { Median } \\
75 \% \\
90 \% \\
99 \% \\
\text { Mean }\end{array}$ & $\begin{array}{l}0.004 \\
0.182 \\
0.666 \\
0.872 \\
0.928 \\
0.956 \\
0.980 \\
0.738 \\
\end{array}$ & $\begin{array}{l}0.363 \\
0.716 \\
0.864 \\
0.930 \\
0.958 \\
0.973 \\
0.988 \\
0.880 \\
\end{array}$ \\
\hline
\end{tabular}

-0.13 (average $t$-statistic of 8.90) across all quarters and condominium projects. Thus, large units sell at a PSF discount compared to small units. The average $\beta_{\mathrm{f}}$ coefficient is 7.15 (average $t$-statistic of 6.13), indicating a price premium for units on higher floors. Overall, the large explanatory power from equation (1) demonstrates that unobservable unit-level attributes exert little impact on PSF prices.

We then use the condominium project-level coefficients from the extended hedonic model to estimate unit-level market prices within each condominium project. A unit's estimated PSF price in quarter $t$, denoted $\mathrm{PSF}_{i, t}$, is determined by its size and floor level in addition to the quarterly dummy coefficient for next quarter

$$
\mathrm{PSF}_{i, t}=\widehat{\beta}_{t+1}+\widehat{\beta}_{\mathrm{s}} \operatorname{LOG}(\mathrm{SIZE})_{i}+\widehat{\beta}_{\mathrm{f}} \text { FLOOR_LEVEL }{ }_{i} \text {. }
$$

To ensure the accuracy of our hedonic model, we remove condominium projects whose adjusted $R^{2}$ from the hedonic model is below $70 \%$. We use the quarterly dummy coefficient $\widehat{\beta}_{t+1}$ for next quarter to avoid underestimating market prices because units are more likely to be sold when market prices are increasing. In particular, for the full sample, the average selling price premium computed later in equation (5) is close to zero using the predicted PSF from equation (2). Nonetheless, our results are similar if the quarterly dummy coefficient $\widehat{\beta}_{t}$ for quarter $t$ replaces $\widehat{\beta}_{t+1}$ in equation (2).

\section{Empirical Results}

This section describes the results from our empirical tests that determine the influence of gains and losses on sell propensities. 


\section{A. Sell Propensities}

Following Odean (1998), we first estimate the following ratio

$$
R=\frac{\text { PGR }}{\text { PLR }}=\frac{\text { Probability of Realizing a Gain }}{\text { Probability of Realizing aLoss }} .
$$

PGR represents the probability of a gain being realized and is defined as the percentage of units with an unrealized gain that are sold in quarter $t+1$. Similarly, PLR represents the probability of a loss being realized and is defined as the percentage of units with an unrealized loss that are sold in quarter $t+1$. Unrealized gains and losses are estimated in quarter $t$ using equation (2).

In unreported results, the ratio $R$ averages 1.765 . A $t$-statistic of 5.13, computed from the distribution of the ratio's time series over the sample period, rejects the null hypothesis that $R$ equals 1 . Typically, researchers conclude that this evidence supports the disposition effect. However, Ben-David and Hirshleifer (2012) emphasize that the bundling of gains and losses, irrespective of their magnitude, can lead to the spurious conclusion that positions with a gain are more likely to be sold than positions with a loss. Therefore, these authors test the disposition effect by determining whether there is a discontinuity in the sell propensities between small gains and small losses.

As illustrated by Figure 1, all hypotheses regarding seller behavior have the average sell propensity of gains being higher than the average sell propensity of losses. This motivates the need to examine sell propensities across the full schedule of return magnitudes.

Figure 3 plots unit-level sell propensities conditional on their respective return since purchase using equation (2) to estimate each unit's market price. In our main analysis, we focus on units whose holding period is 3 years or less. Note that a unit's holding period refers to the amount of time that has elapsed since its most recent purchase date, not the start of our sample period. Ben-David and Hirshleifer (2012) argue that short holding periods are more appropriate for testing the disposition effect. In our analysis, short holding periods identify transactions more likely to be associated with an investment motive instead of a consumption or bequest motive.

To plot the sell propensities for such short-term units in the top chart in Figure 3, we sort each quarter-unit observation into bins whose width is $1 \%$ where we exclude bins with fewer than 100 observations. For each bin, we then compute the percentage of units sold next quarter. As predicted by realization utility, Figure 3 reveals that a larger gain increases a unit's sell propensity. The bottom chart focuses on absolute returns within $20 \%$ and shows the sell propensities to be mostly flat before zero and upward sloping after returns change from being negative to positive. This indicates that unit's purchase price is indeed the reference price utilized by sellers. ${ }^{7}$ These charts provide support for realization utility since the upward slope is consistent with investors deriving greater utility from realizing larger gains.

Overall, the plots in Figure 3 most closely resemble the Graph B in Figure 1 since the sell propensities are flat over losses and increasing with the magnitude of

\footnotetext{
${ }^{7}$ A later section examines the impact of transaction costs.
} 
FIGURE 3

\section{Sell Propensity of Short-Term Units}

Graph A in Figure 3 plots the sell propensity against a unit's return since purchase for all units whose holding period is $\leq 3$ years. For this sample, Graph B plots sell propensities for units whose return since purchase is between $-20 \%$ and $20 \%$. A unit's market price is determined using the hedonic model in equation (2) provided the adjusted $R^{2}$ in the condominium project exceeds 0.70. For Graph A, the dots are the average of observations in 1\%-bins, and for Graph B, the bin size is $0.1 \%$. Bins with fewer than 100 observations are excluded.

Graph A. Full Schedule of Return Since Purchase

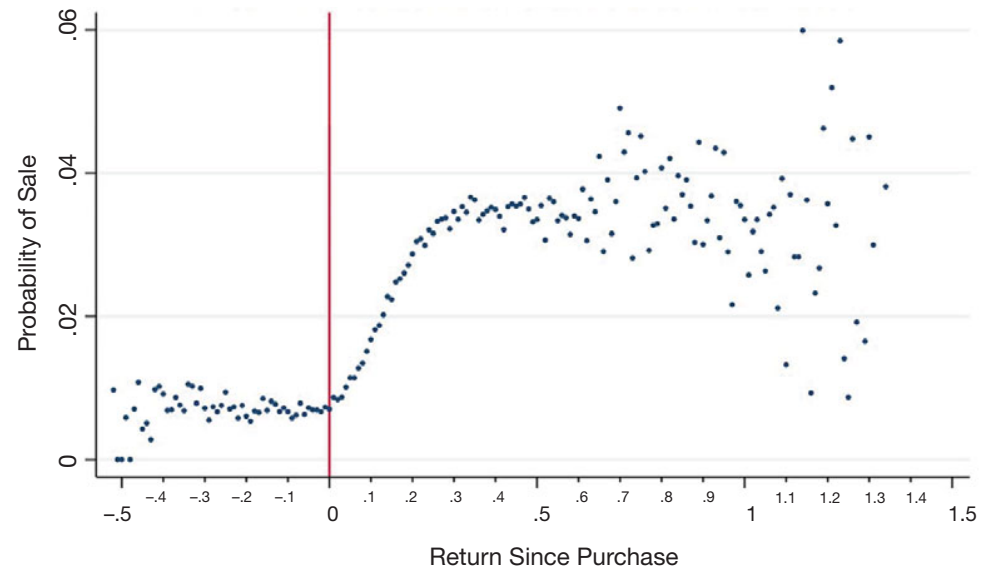

Graph B. Absolute Return Since Purchase Within 20\%

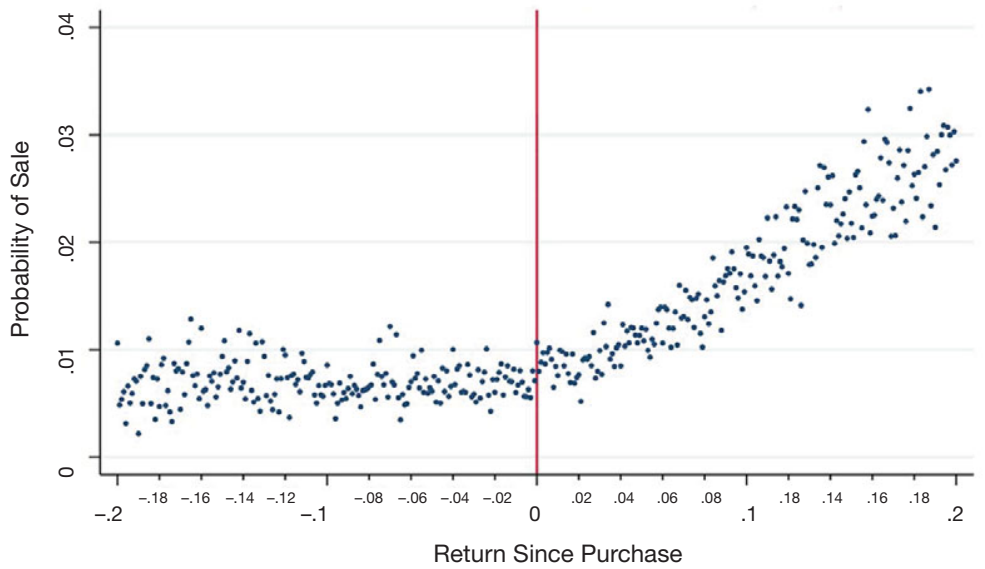

gains. Thus, realization utility appears to have the strongest visual support among the 4 hypotheses.

To formally examine the relation between unit-level gains and sell propensities, we estimate a probit model that controls for several unit-level and market-level characteristics

$$
1_{\mathrm{SALE}}=\Phi\left(\alpha_{1} 1_{\mathrm{RETURN}>0}+\alpha_{2} \mathrm{RETURN}^{+}+\alpha_{3} \mathrm{RETURN}^{-}+\gamma X\right) .
$$


The dependent variable, $1_{\mathrm{SALE}}$, equals 1 if a unit is sold in quarter $t+1$ and its capital gain is estimated in quarter $t$ using equation (2). RETURN ${ }^{+}$is defined as MAX(RETURN, 0) and RETURN ${ }^{-}$is defined as MIN(RETURN, 0) where RETURN is defined as a unit's return since purchase. Following Ben-David and Hirshleifer (2012), we include a control for units whose RETURN is positive $\left(1_{\text {RETURN }}>0\right)$.

Independent variables include the length of the unit's HOLDING_PERIOD (years since purchase), the log of the unit's square footage (SIZE), and the unit's FLOOR_LEVEL. The latter 2 variables are known to have pricing implications based on the results from equation (1). For ease of interpretation, the actual floor level is divided by 100 , which magnifies its coefficient by 100 . Thus, while the FLOOR_LEVEL coefficients are often statistically significant, their economic significance is minimal.

We also include variables that proxy for financing constraints. A dummy variable PUBLIC_HOUSING equals 1 if the unit's buyer lived in public housing at the time of the unit's purchase. This proxies for the unit's buyer being more financially constrained compared to buyers who were already living in private housing at the time of the unit's purchase. ${ }^{8}$ Another proxy for financing constraints is the unit's PAID-IN_EQUITY since the ability of price declines to tighten financing constraints is more severe for sellers with low equity in their current property. We proxy for unit-level equity by aggregating each unit's down payment and subsequent monthly principal payments. This sum is then normalized by the unit's estimated price to create a PAID-IN_EQUITY measure. While PAID-IN_EQUITY is not directly related to a unit's gain, both can alleviate financing constraints. To compute this variable, we assume that a unit's down payment equals the government-mandated minimum based on the prevailing maximum loan-to-value ratio at its purchase date. ${ }^{9}$ Mortgages in Singapore are standardized with a maturity of 30 years and an adjustable rate that references the 3-month interbank offer rate in Singapore (SIBOR). The actual mortgage rate is typically $1 \%$ above SIBOR. ${ }^{10}$ The standardization of mortgages in Singapore enables monthly principal payments to be aggregated depending on each unit's purchase date and the relevant SIBOR time series. ${ }^{11}$

\footnotetext{
${ }^{8}$ A unique feature of Singapore's housing market is its segmentation into public units and private units. Although the majority of Singapore citizens live in public housing, they usually intend to upgrade to a condominium unit when their financial circumstances permit. Although the URA data contain private condominium transactions and not public housing transactions, it does indicate whether the buyer of a condominium unit was residing in public housing at the time the condominium unit was purchased.

${ }^{9}$ The Singapore government adjusts the maximum loan-to-value ratio in a counter-cyclical manner to counteract large moves in housing prices. We collect data on these policy adjustments from various government websites and newspaper articles.

${ }^{10}$ Variation in the mortgage rate above SIBOR is small compared to time-series variation in SIBOR. As mortgages in Singapore are recourse and default rates are correspondingly low, the premium above SIBOR is stable across time and across owners. Recourse mortgages mitigate strategic defaults by real estate investors. Agarwal, Green, Rosenblatt, and Yao (2015) find that larger down payments also mitigate strategic defaults.

${ }^{11}$ Genesove and Mayer (1997) also assume a common maturity and borrowing rate in their equity calculation. We begin computing principal payments 3 months after a unit's purchase date since housing transactions usually require 12 weeks to complete in Singapore.
} 
Two quarterly proxies for market-level financing constraints are also included: the SIBOR rate in the prior quarter and the minimum required down payment expressed as a percentage (e.g., DOWN_PAYMENT of 0.20 denotes a $20 \%$ required down payment). For an individual unit, a higher down payment implies PAID-IN_EQUITY is initially higher. Increases in the minimum down payment mandated by the government occur in response to dramatic property price increases. ${ }^{12}$ Monthly principal repayments regularly increase PAIDIN_EQUITY, with this increase depending on a unit's holding period as well as SIBOR.

Finally, FREEHOLD is a dummy variable that equals 1 when a condominium project's lease period is either perpetual or $800+$ years. Giglio et al. (2015) show that compared to leasehold properties, such properties sell at a larger than expected premium.

Table 3 contains the results of the probit estimations based on units with short holding periods of 3 years or less. For continuous independent variables, we report the marginal impact on the sell probability when the variable changes by 1 standard deviation (half a standard deviation below to half a standard deviation above its mean). For binary independent variables, the reported marginal effect is the difference in the sell probability when this variable changes from 0 to 1 . Marginal effects are reported in percentages, and $z$-statistics for probit models ( $t$-statistics for OLS models), based on standard errors clustered by calendar quarter, are reported in parentheses. The last specification in each estimation set includes high-dimensional fixed effects (quarter fixed effects and condominium project fixed effects). This specification is estimated by a linear probability model (Gormley and Matsa (2014)) as nonlinear models estimated with fixed effects result in biased estimates (Greene (2002)). In this specification, the condominium project-specific and quarter-specific control variables, namely FREEHOLD, SIBOR, and DOWN_PAYMENT are dropped.

Models $1-5$ of Table 3 reports the results using the full sample of returns. Observe that the marginal effect for the DUMMY(RETURN > 0) variable is positive in every specification. Thus, sell propensities are higher for units with a gain. The sell propensities also increase with the magnitude of a unit's gain as the positive marginal effect for RETURN $^{+}$in every specification indicates that sell propensities have a positive relation with a unit's return since purchase. The dependence of the sell propensities on gains indicates that sell propensities do not conform to the step-function in Graph A of Figure 1. In contrast to the marginal effect for RETURN ${ }^{+}$, the sign of the marginal effect for RETURN ${ }^{-}$is mixed and not always significant. There is also no evidence of any $\mathrm{V}$-shape in the sell propensities as the marginal effect of RETURN ${ }^{-}$is never significantly negative.

In models 6-10, we report estimates using a subsample with absolute return since purchase within $20 \%$ to focus on units that are more likely to be held for

\footnotetext{
${ }^{12}$ Down payment requirements usually increase during property booms as the Singapore government's lending policies are counter cyclical. By increasing down payments during property booms, property price increases tighten financing constraints. This differs from the prediction of Stein (1995) that assumes price increases relax financing constraints. Thus, real estate transactions in Singapore are ideal for testing the predictions of realization utility since this alternative hypothesis is partially mitigated.
} 
TABLE 3

Unit-Level Sell Propensities for Short Holding Periods

Table 3 records the marginal effects (in percentages) from a probit panel estimation that examines unit-level sell probabilities for units with short holding periods (defined as periods $\leq 3$ years) in each quarter of our 1998-2012 sample. The dependent variable equals 1 if a unit is sold in quarter $t+1$ after its capital gain is estimated. RETURN is estimated by subtracting a unit's purchase price from its estimated market price, and then normalizing this difference by the purchase price. A unit's market price is determined using the hedonic model in equation (2) provided the adjusted $R^{2}$ in the condominium project exceeds 0.70 . RETURN ${ }^{+}$is defined as MAX(RETURN, 0) and RETURN ${ }^{-}$is defined as MIN(RETURN, 0 ). DUMMY (RETURN>0) is an indicator variable for units with a capital gain. The unit's HOLDING_PERIOD, defined as the number of years since its purchase, is also included in the probit along with the unit's square footage (SIZE) and FLOOR_LEVEL (divided by 100). Unit-level control variables for financing constraints include a FUBLIC_HOUSING indicator variable that equals 1 if the unil's buyer was a resident of public housing at the time of its purchase, and PAIDIN_EQUITY, which is defined as the sum of a unit's estimated down payment and cumulative principal repayments normalized by its market price at the quarter-end. FREEHOLD is a dummy variable that equals 1 when a condominium project's lease period is either perpetual or 800 + years. Market-level financing constraints include the prevalling 3-month interbank offer rate in Singapore (SIBOR), which monthly mortgage payments are based on, and DOWN_PAYMENT, the prevailing

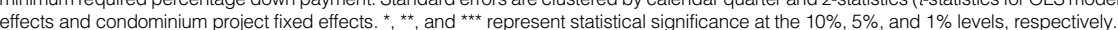

Short Holding Period

DUMMY (RETURN > $)$

RETURN $^{+}$

RETURN $^{-}$

HOLDING_PERIOD

LOG(SIZE)

FLOOR_LEVEL

PUBLIC_HOUSING

PAID-IN_EQUITY

FREEHOLD

LAG(SIBOR)

DOWN_PAYMENT

\section{No. of obs.}

Pseudo or Adj. $R^{2}$

Estimation

Quarter Fixed Effects

Condo Project Fixed Effects

\begin{tabular}{|c|c|}
\hline 1 & 2 \\
\hline \multirow[t]{3}{*}{$\begin{array}{l}1.659^{\star \star \star} \\
(12.13)\end{array}$} & $\begin{array}{c}1.312^{\star \star \star} \\
(11.39)\end{array}$ \\
\hline & $\begin{array}{l}1.825^{\star \star \star} \\
(7.55)\end{array}$ \\
\hline & $\begin{array}{c}-0.323 \\
(-0.40)\end{array}$ \\
\hline
\end{tabular}

\begin{tabular}{|c|c|c|}
\hline 3 & 4 & 5 \\
\hline \multirow[t]{3}{*}{$\begin{array}{l}1.067^{\star \star \star} \\
(9.47)\end{array}$} & $\begin{array}{c}0.937^{\star \star \star} \\
(10.59)\end{array}$ & $\begin{array}{l}0.450^{\star \star \star \star} \\
(3.87)\end{array}$ \\
\hline & $\begin{array}{l}0.924^{\star \star} \\
(2.28)\end{array}$ & $\begin{array}{l}1.225^{\star \star} \\
(2.20)\end{array}$ \\
\hline & $\begin{array}{l}2.229^{\star \star} \\
(1.99)\end{array}$ & $\begin{array}{l}1.413^{*} \\
(1.96)\end{array}$ \\
\hline $\begin{array}{c}0.662^{\star \star \star} \\
(11.63)\end{array}$ & $\begin{array}{l}0.519^{\star \star \star} \\
(5.54)\end{array}$ & $\begin{array}{l}0.823^{\star \star \star} \\
(10.05)\end{array}$ \\
\hline $\begin{array}{c}-0.750^{\star \star \star} \\
(-12.45)\end{array}$ & $\begin{array}{l}-0.714^{\star \star \star} \\
(-11.32)\end{array}$ & $\begin{array}{l}-1.208^{\star \star \star} \\
(-9.65)\end{array}$ \\
\hline $\begin{array}{l}1.053^{\star \star \star} \\
(3.68)\end{array}$ & $\begin{array}{l}0.819^{\star \star \star} \\
(3.77)\end{array}$ & $\begin{array}{l}0.695^{\star \star} \\
(2.61)\end{array}$ \\
\hline $\begin{array}{l}-0.308^{\star \star \star} \\
(-6.40)\end{array}$ & $\begin{array}{l}-0.309^{\star \star \star} \\
(-6.51)\end{array}$ & $\begin{array}{l}-0.212^{\star \star \star} \\
(-5.72)\end{array}$ \\
\hline $\begin{array}{l}-5.578^{\star \star \star} \\
(-2.78)\end{array}$ & $\begin{array}{c}0.639 \\
(0.25)\end{array}$ & $\begin{array}{l}-5.630^{\star \star \star} \\
(-4.83)\end{array}$ \\
\hline $\begin{array}{l}0.104^{\star \star \star} \\
(3.55)\end{array}$ & $\begin{array}{l}0.107^{\star \star \star} \\
(3.59)\end{array}$ & \\
\hline $\begin{array}{c}0.122 \\
(1.58)\end{array}$ & $\begin{array}{l}0.143^{*} \\
(1.80)\end{array}$ & \\
\hline $\begin{array}{l}-4.817^{\star \star} \\
(-2.33)\end{array}$ & $\begin{array}{l}-10.161^{\star \star \star} \\
(-3.75)\end{array}$ & \\
\hline $\begin{array}{l}1,878,999 \\
0.0580 \\
\text { Probit } \\
\text { No } \\
\text { No }\end{array}$ & $\begin{array}{l}1,878,999 \\
0.0589 \\
\text { Probit } \\
\text { No } \\
\text { No }\end{array}$ & $\begin{array}{l}1,878,999 \\
0.0170 \\
\text { OLS } \\
\text { Yes } \\
\text { Yes }\end{array}$ \\
\hline
\end{tabular}

Short Holding Period, Absolute Return Within 20\%

\begin{tabular}{|c|c|c|c|c|}
\hline 6 & 7 & 8 & 9 & 10 \\
\hline \multirow[t]{11}{*}{$\begin{array}{l}0.935^{\star \star \star} \\
(10.91)\end{array}$} & $\begin{array}{l}0.140^{\star \star} \\
(2.36)\end{array}$ & $\begin{array}{l}0.622^{\star \star \star} \\
(8.35)\end{array}$ & $\begin{array}{l}0.156^{\star \star \star} \\
(3.49)\end{array}$ & $\begin{array}{l}-0.082 \\
(-1.38)\end{array}$ \\
\hline & $\begin{array}{l}8.072^{\star \star \star} \\
(13.23)\end{array}$ & & $\begin{array}{l}4.730^{\star \star \star} \\
(7.61)\end{array}$ & $\begin{array}{l}7.281^{\star \star \star} \\
(9.20)\end{array}$ \\
\hline & $\begin{array}{c}0.042 \\
(0.05)\end{array}$ & & $\begin{array}{l}2.398^{\star \star \star} \\
(3.37)\end{array}$ & $\begin{array}{l}3.255^{\star \star \star} \\
(3.39)\end{array}$ \\
\hline & & $\begin{array}{l}0.645^{\star \star \star} \\
(11.37)\end{array}$ & $\begin{array}{l}0.481^{\star \star \star} \\
(8.17)\end{array}$ & $\begin{array}{l}0.832^{\star \star \star} \\
(10.23)\end{array}$ \\
\hline & & $\begin{array}{l}-0.498^{\star \star \star} \\
(-10.60)\end{array}$ & $\begin{array}{l}-0.424^{\star \star \star} \\
(-8.96)\end{array}$ & $\begin{array}{l}-0.908^{\star \star \star} \\
(-6.96)\end{array}$ \\
\hline & & $\begin{array}{l}0.454^{\star \star \star} \\
(2.72)\end{array}$ & $\begin{array}{c}0.214 \\
(1.47)\end{array}$ & $\begin{array}{r}0.297 \\
(1.06)\end{array}$ \\
\hline & & $\begin{array}{l}-0.247^{\star \star \star} \\
(-7.75)\end{array}$ & $\begin{array}{l}-0.255^{\star \star \star} \\
(-8.54)\end{array}$ & $\begin{array}{l}-0.240^{\star \star \star} \\
(-5.89)\end{array}$ \\
\hline & & $\begin{array}{l}-4.271^{\star \star \star} \\
(-3.03)\end{array}$ & $\begin{array}{c}1.940 \\
(1.18)\end{array}$ & $\begin{array}{l}-2.830^{\star \star \star} \\
(-2.70)\end{array}$ \\
\hline & & $\begin{array}{l}0.072^{\star \star \star} \\
(3.05)\end{array}$ & $\begin{array}{l}0.062^{\star \star \star} \\
(2.92)\end{array}$ & \\
\hline & & $\begin{array}{c}0.012 \\
(0.30)\end{array}$ & $\begin{array}{c}0.049 \\
(1.28)\end{array}$ & \\
\hline & & $\begin{array}{l}-4.079^{\star \star \star} \\
(-2.64)\end{array}$ & $\begin{array}{l}-9.369^{\star \star \star} \\
(-5.43)\end{array}$ & \\
\hline $1,298,169$ & $1,298,169$ & $1,236,763$ & $1,236,763$ & $1,236,761$ \\
\hline 0.0139 & 0.0250 & 0.0674 & 0.0720 & 0.0163 \\
\hline Probit & Probit & Probit & Probit & OLS \\
\hline No & No & No & No & Yes \\
\hline No & No & No & No & Yes \\
\hline
\end{tabular}

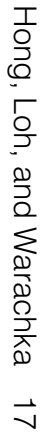


investment. In realization utility, if an asset is held for investment and has a very large gain, the investor's threshold for obtaining utility from realizing the gain is likely to have been already reached. Hence, an unsold unit with a large gain is less likely to be held for investment. We see that the marginal effects for RETURN ${ }^{+}$are large, positive, and statistically significant. The marginal effects for RETURN ${ }^{-}$are mixed-not always significantly positive, and never significantly negative.

We next discuss the marginal effects associated with the financing constraints proxies. Consistent with financing constraints, the negative coefficients for PUBLIC_HOUSING suggest that previous residents of public housing, who are more financially constrained, are less likely to sell their unit. In contrast, the negative coefficients for PAID-IN_EQUITY and DOWN_PAYMENT are inconsistent with financing constraints as more equity in a unit reduces its sell propensity. Although some of the estimated marginal effects over losses are positive, there is no consistent corroborating evidence when we examine the marginal effects of the other financing constraints variables on selling behavior.

In summary, our results support the realization utility theory in Barberis and Xiong (2012) with sell propensities that are mostly flat over losses and upward sloping over gains. ${ }^{13}$

\section{B. Selling Prices}

Unlike the stock market where transaction prices are largely exogenous with respect to the seller, the real estate market enables us to investigate whether transaction prices depend on a seller's gain. Transaction prices are partially endogenous in the real estate market since sellers decide whether to accept or reject a prospective buyer's offer. Therefore, we examine if a unit's gain influences the price accepted by the seller.

Our analysis of selling prices is not a formal test of any explicit realization utility prediction since selling prices are exogenous and defined ex ante in realization utility models. The objective of this analysis is hence modest. We conjecture that sellers with a large unrealized capital gain are more willing to accept a price concession (accept an offer below their property's market price). Of course, if a lower selling price is agreed to, the seller understands their realized capital gain is also lower. Therefore, a price concession is unlikely if the seller has a small gain since accepting a lower offer endangers this small gain. Hence, the impact of gains on selling prices is not expected to be economically large.

To analyze the selling prices, for each sale transaction, we compute the unit's selling price premium by subtracting 1 from the ratio of its observed sale price normalized by its estimated market price from equation (2) in quarter $t$. This selling price premium is the dependent variable in the following empirical specification

\footnotetext{
${ }^{13}$ In unreported tests, we add a dummy variable that indicates a unit has negative equity. Adding this control does not affect our results. The sign on this dummy variable is mixed. As negative equity is likely to occur only when a purchase is quickly faced with a sharp market downturn that depletes the down payment and any principal repaid, it is unlikely to be a good proxy for a liquidity shock that is random to an individual investor. A negative equity dummy hence serves more like a proxy for large losses. Since we find that the effect of loss magnitude on sell propensity is mixed, it is not surprising that a negative equity dummy also has a mixed impact on sell propensities.
} 


$$
\begin{aligned}
\frac{\text { Selling Price }}{\text { Estimated Price }}-1= & \alpha_{0}+\alpha_{1} 1_{\text {RETURN }>0}+\alpha_{2} \text { RETURN_RANK } \\
& +\alpha_{3} \text { RETURN_RANK }^{-}+\gamma X+\varepsilon .
\end{aligned}
$$

RETURN_RANK ${ }^{+}$equals $1-5$ for 5 return since purchase bins ranging over $(0 \%, 5 \%],(5 \%, 10 \%],(10 \%, 20 \%],(20 \%, 30 \%]$, and $>30 \%$, respectively. Similarly, RETURN_RANK ${ }^{-}$equals -5 to -1 for 5 return bins ranging over $<-30 \%$, $[-30 \%,-20 \%),[-20 \%,-10 \%),[-10 \%,-5 \%)$, and $[-5 \%, 0 \%]$, respectively. We use signed group ranks instead of actual continuous returns to mitigate any potential mechanical link between the RHS and LHS of equation (5). The $\boldsymbol{X}$ vector includes multiple control variables from our earlier sell propensity specifications. We estimate equation (5) by OLS and cluster the standard errors by calendar quarter with $t$-statistics reported in parentheses. Coefficient estimates are reported in percentages.

Before reporting our estimation results, Figure 4 illustrates the univariate relation between selling price premiums and returns for units whose holding period is 3 years or less. Each point in this figure represents the average selling price premium for a particular return since purchase. Returns are divided into $1 \%$ bins for the top chart with the full schedule of returns (bins with fewer than 10 observations are excluded) and $0.1 \%$ bins for the bottom chart with absolute returns within $20 \%$ (bins with fewer than 5 observations are excluded). We observe that selling prices are lower for units with a larger gain. Units with a loss sell at a slight premium above their estimated market price, while the selling premium appears to be lower for units with a gain.

The visual characterization of the sell propensities in Figure 4 is confirmed by the estimation results in Table 4. The marginal effect for RETURN_RANK ${ }^{+}$ determines whether the unrealized return since purchase magnitude groups have any impact on selling prices between these groups. Specifically, a negative coefficient indicates that sellers with a larger gain appear to accept a lower selling price in order to realize their gain. The coefficient in model 4 indicates that the effect is $-0.764 \%$ in each gain group. Thus, a single-rank increase in RETURN_RANK ${ }^{+}$ reduces the selling price premium by $76 \mathrm{bps}$. Limiting the estimations to returns whose absolute value is within $20 \%$ yield similar coefficients for RETURN_RANK ${ }^{+}$. In contrast, the signs of the coefficients for the loss group variable RETURN_RANK ${ }^{-}$are mixed.

Our selling price evidence is consistent with sellers accepting price concessions in order to realize large gains. In other words, the lower selling prices associated with larger gains facilitate transactions and therefore higher sell propensities.

In unreported tests, we estimate the same regression using dummy variables to represent each quintile group, with groups 1 and -1 being the baseline. The impact of gains on selling prices are modest as the second gain group (group 2) is associated with a selling discount of $0.38 \%$, while the highest gain group (group 5) is associated with a selling discount of $2.86 \%$ when all control variables are included. Hence, price concessions for units with a small gain are not large enough to negate 
FIGURE 4

\section{Selling Price Premium of Short-Term Units}

Figure 4 plots the selling price premium against the magnitude of a unit's return since purchase for all units whose holding period is $\leq 3$ years. The unit's selling price is computed by subtracting 1 from the ratio of its observed sale price in quarter $t+1$ normalized by its estimated market price from equation (2), provided the adjusted $R^{2}$ in the condominium project exceeds 0.70 . Graph A plots this premium for the full schedule of return since purchase where the dots are the average of observations in 1\%-bins (bins with fewer than 10 observations are excluded). Graph B plots this premium for units whose return since purchase is between $-20 \%$ and $20 \%$ where the bin size is $0.1 \%$ (bins with fewer than 5 observations are excluded).
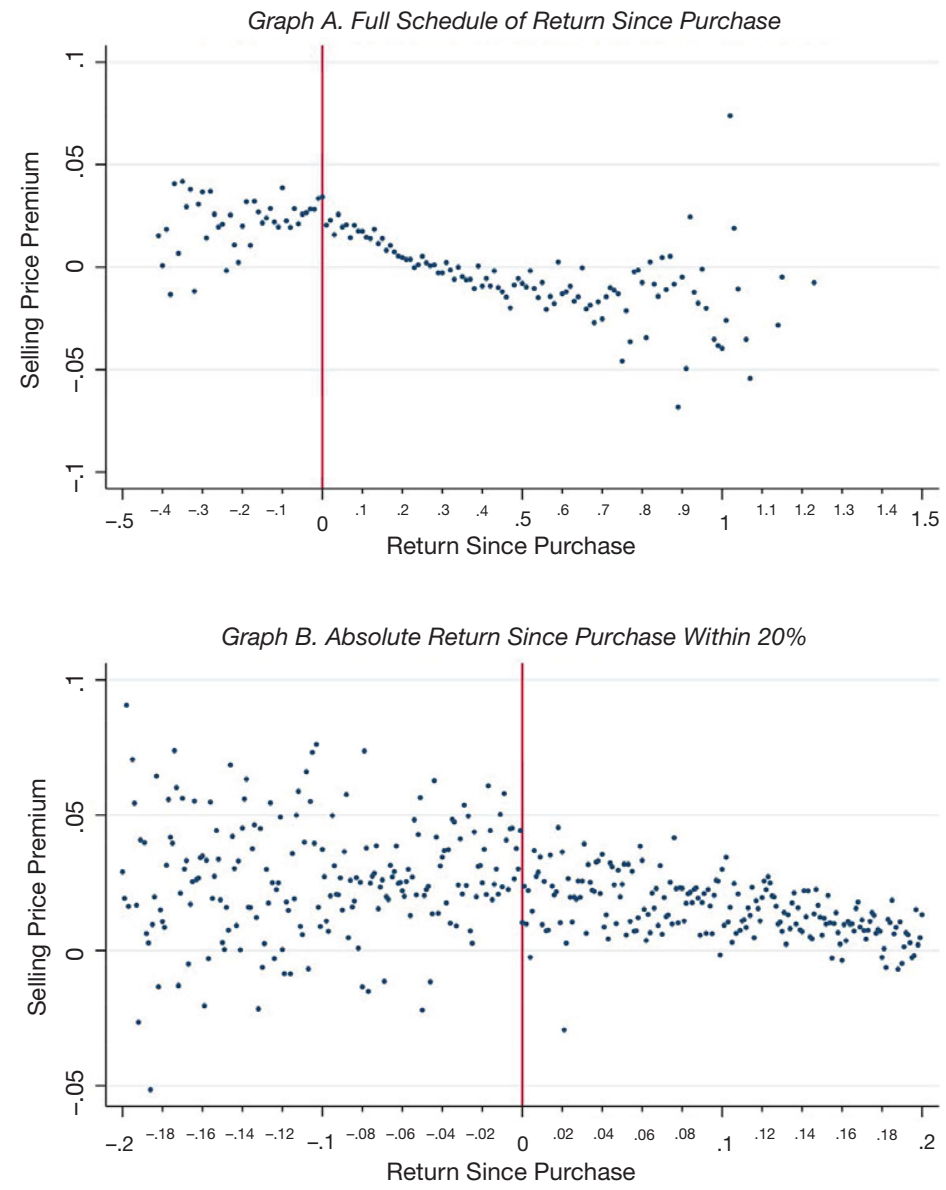

the gain. In contrast, the negative gain groups have coefficients that are mostly insignificant, indicating that selling price premiums are flat over losses.

Although not a clear prediction of realization utility, our selling price results may offer an interesting behavioral implication that is compatible with realization utility: higher sell propensities are facilitated by sellers with larger gains accepting price concessions. 
TABLE 4

Selling Prices for Short Holding Periods

Table 4 records the coefficients (in percentages) from an OLS regression whose dependent variable is a unit's selling price premium for units with short holding periods (defined as $\leq 3$ years) based on quarterly observations from 1998 to 2012. The selling premium is computed by subtracting 1 from the ratio of a unit's selling price in quarter $t+1$ normalized by its estimated market price in quarter $t$. A unit's market price is estimated using the hedonic model in equation (2)

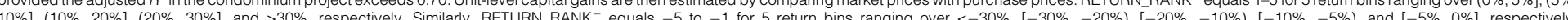
DUMMY (RETURN $>0$ ) is an indicator variable for units with a capital gain. The unit's HOLDING_PERIOD, defined as the number of years since its purchase, is also included along with the unit's square footage (SIZE) and FLOOR LEVEL (divided by 100). Unit-level control variables for financing constraints include a PUBLIC HOUSING indicator variable that equals 1 if the unit's buyer was a resident of public housing at the time of its purchase, and PAID-IN_EQUITY, which is defined as the sum of a unit's estimated down payment and cumulative principal repayments normalized by its market price at the quarter-end. FREEHOLD is a dummy variable that equals 1 when a condominium project's lease period is either perpetual or $800+$ years. Market-level financing constraints include the prevailing 3-month interbank offer rate in Singapore (SIBOR), which monthly mortgage payments are based on, and DOWN_PAYMENT, the prevailing minimum required percentage down payment. Standard errors are clustered by calendar quarter and $t$-statistics are reported in parentheses. Models 5 and 10 are estimated with calendar quarter fixed effects and condominium project fixed effects. ${ }^{\star},{ }^{\star \star}$, and ${ }^{\star \star \star}$ represent statistical significance at the $10 \%, 5 \%$, and $1 \%$ levels, respectively.

DUMMY(RETURN>0)

RETURN_RANK ${ }^{+}$

RETURN_RANK

HOLDING_PERIOD

LOG(SIZE)

FLOOR_LEVEL

PUBLIC_HOUSING

PAID-IN_EQUITY

FREEHOLD

$\operatorname{Lag}(\mathrm{SIBOR})$

DOWN_PAYMENT

No. of obs

Adj. $R^{2}$

Quarter fixed effects

Condo project fixed effects

Predicted $\mathrm{Y}(\%)$

\section{Short Holding Period}

\begin{tabular}{ccc}
\hline 1 & & 2 \\
$-2.253^{\star \star \star}$ & & 0.412 \\
$(-9.11)$ & & $(1.41)$ \\
& $-0.821^{\star \star \star}$ \\
& $(-13.34)$ \\
& $0.283^{\star \star}$ \\
& $(2.12)$
\end{tabular}

$\frac{3}{-0.901^{\star \star \star}}$

\begin{tabular}{ccc}
4 & & 5 \\
\cline { 1 - 1 } 0.254 & & $0.434^{\star}$ \\
$(0.89)$ & & $(1.78)$ \\
$-0.764^{\star \star \star}$ & & $-1.324^{\star \star \star}$ \\
$(-8.51)$ & & $(-16.03)$ \\
$0.363^{*}$ & & $-0.355^{* *}$ \\
$(1.73)$ & & $(-2.08)$ \\
$-0.580^{\star \star \star}$ & & $-0.180^{\star}$ \\
$(-6.12)$ & & $(-1.68)$ \\
-0.398 & & -1.276 \\
$(-0.80)$ & & $(-1.24)$ \\
0.810 & & $2.905^{\star}$ \\
$(0.90)$ & & $(1.94)$ \\
-0.101 & & -0.076 \\
$(-1.00)$ & & $(-0.75)$ \\
6.233 & & $-3.549^{\star}$ \\
$(1.21)$ & & $(-1.85)$ \\
$-0.157^{\star \star}$ & & \\
$(-2.05)$ & & \\
0.045 & & \\
$(0.42)$ & & \\
$-9.373^{* \star}$ & \\
$(-2.38)$ & \\
33,898 & 33,882 \\
0.0343 & 0.0575 \\
No & Yes \\
No & Yes \\
0.591 & 0.591 \\
& & \\
& &
\end{tabular}

\begin{tabular}{|c|c|c|c|c|}
\hline 6 & 7 & 8 & 9 & 10 \\
\hline \multirow[t]{11}{*}{$\begin{array}{l}-1.284^{\star \star \star} \\
(-5.47)\end{array}$} & $\begin{array}{l}-0.189 \\
(-0.62)\end{array}$ & $\begin{array}{l}-1.388^{\star \star \star} \\
(-5.43)\end{array}$ & $\begin{array}{l}-0.150 \\
(-0.50)\end{array}$ & $\begin{array}{l}-0.124 \\
(-0.46)\end{array}$ \\
\hline & $\begin{array}{l}-0.550^{\star \star \star} \\
(-4.64)\end{array}$ & & $\begin{array}{l}-0.696^{\star \star \star} \\
(-4.95)\end{array}$ & $\begin{array}{l}-1.247^{\star \star \star} \\
(-10.78)\end{array}$ \\
\hline & $\begin{array}{c}0.243 \\
(1.25)\end{array}$ & & $\begin{array}{l}0.080 \\
(0.33)\end{array}$ & $\begin{array}{l}-0.471^{\star \star} \\
(-2.34)\end{array}$ \\
\hline & & $\begin{array}{l}-1.466^{\star \star \star} \\
(-8.18)\end{array}$ & $\begin{array}{l}-1.218^{\star \star \star} \\
(-5.96)\end{array}$ & $\begin{array}{l}-0.670^{\star \star \star} \\
(-4.29)\end{array}$ \\
\hline & & $\begin{array}{l}-0.610^{\star} \\
(-1.91)\end{array}$ & $\begin{array}{l}-0.733^{\star \star} \\
(-2.31)\end{array}$ & $\begin{array}{l}-1.486^{\star \star} \\
(-2.07)\end{array}$ \\
\hline & & $\begin{array}{l}0.042 \\
(0.04)\end{array}$ & $\begin{array}{c}0.383 \\
(0.41)\end{array}$ & $\begin{array}{l}-3.297^{\star \star \star}, \\
(-3.01)\end{array}$ \\
\hline & & $\begin{array}{l}-0.145 \\
(-0.87)\end{array}$ & $\begin{array}{l}-0.119 \\
(-0.70)\end{array}$ & $\begin{array}{c}0.101 \\
(0.65)\end{array}$ \\
\hline & & $\begin{array}{l}11.730^{*} \\
(1.90)\end{array}$ & $\begin{array}{c}0.500 \\
(0.07)\end{array}$ & $\begin{array}{l}-10.316^{\star \star \star} \\
(-5.20)\end{array}$ \\
\hline & & $\begin{array}{l}-0.557^{\star \star \star} \\
(-4.30)\end{array}$ & $\begin{array}{l}-0.545^{\star \star \star} \\
(-4.20)\end{array}$ & \\
\hline & & $\begin{array}{l}-0.028 \\
(-0.19)\end{array}$ & $\begin{array}{l}-0.061 \\
(-0.38)\end{array}$ & \\
\hline & & $\begin{array}{l}-16.925^{\star \star \star} \\
(-2.92)\end{array}$ & $\begin{array}{l}-6.976 \\
(-1.10)\end{array}$ & \\
\hline 16,085 & 16,085 & 15,287 & 15,287 & 15,244 \\
\hline 0.00646 & 0.00964 & 0.0341 & 0.0382 & 0.100 \\
\hline No & & No & No & Yes \\
\hline No & No & No & No & Yes \\
\hline 1.724 & 1.724 & 1.761 & 1.761 & 1.763 \\
\hline
\end{tabular}




\section{Holding Period Length}

We repeat our analyses of the sell propensities and selling prices over holding periods whose length is $>3$ years, but not more than 5 years (medium term), or longer than 5 years (long term). A longer holding period may indicate a property is being held for consumption rather than investment.

Consistent with a consumption motive being more likely with longer holding periods, the sell propensities in Table 5 offer mixed support for realization utility among units whose holding period exceeds 3 years. When the absolute return since purchase is within $20 \%$ there is some evidence that the marginal effects of RETURN $^{+}$are positive, but these marginal effects are not consistently positive. This lack of consistency indicates that the sell propensities are not reliably increasing with the magnitude of gains for units held for a longer period of time.

In Table 6, we report that selling prices for units with a gain are lower than comparable units for the medium holding period sample. This price concession evidence weakens for units with a long holding period. Hence, the results are similar but not as strong as earlier results for units with a short holding period.

In summary, we find that realization utility exerts a stronger influence on shortterm real estate transactions than real estate transactions involving longer holding periods. This finding is consistent with short-term transactions being more likely to have an investment motive than a consumption motive.

\section{Variation Across Returns}

Another way to increase the likelihood that units are being held for investment is to focus on returns that are less extreme. According to realization utility, investors sell when they reach their gain threshold. For unsold units with a large unrealized gain, the owner either has an even larger gain threshold or the owner is holding the unit for noninvestment reasons (e.g., consumption).

As a robustness test, we vary the range of returns over which the sell propensities are estimated. Our baseline analysis uses gain magnitudes that, in absolute value, are within $20 \%$ of the purchase price. To demonstrate that our results are robust to alternative thresholds, we repeat the estimations for units whose absolute return is within $15 \%$ or $25 \%$.

The sell propensity results in Table 7 for units whose absolute returns are within $15 \%$ or $25 \%$ confirm the robustness of our earlier results in Table 3 . Indeed, the coefficients are largely similar in both tables. Furthermore, the selling price results in Table 8 for units whose absolute return is within $15 \%$ or $25 \%$ corroborate our earlier results in Table 4. Overall, our empirical support for realization utility is robust to several selection criteria intended to identify units more likely to be held for investment.

\section{E. Transaction Costs}

Our baseline tests use the purchase price as the reference price without adjusting the purchase price for transaction costs. One argument for using the purchase price as the reference price is that the purchase price is a salient number that a property owner is likely to anchor on, given they negotiated this price with the 
TABLE 5

Unit-Level Sell Propensities for Medium and Long Holding Periods

Table 5 records the marginal effects (in percentages) from a probit panel estimation that examines unit-level sell probabilities for units with medium and long holding periods in each quarter of our $1998-2012$ sample. The medium holding period (Panel A) is defined as $>3$ years but not more than 5 years, and the long holding period (Panel B) is defined as $>5$ years. The dependent variable equals 1 if a unit is sold in quarter $t+1$ after its capital gain is estimated in quarter $t$. RETURN is estimated by subtracting a unit's purchase price from its estimated market price, and then normalizing this difference by the purchase price. A unit's market price is determined using the hedonic model in equation (2) provided the adjusted $R^{2}$ in the condominium project exceeds 0.70 . RETURN ${ }^{+}$is defined as MAX(RETURN, 0) and RETURN ${ }^{-}$is defined as MIN(RETURN, 0 ). DUMMY (RETURN $>0$ ) is an indicator variable for units with a capital gain. The unit's HOLDING_PERIOD, defined as the number of years since its purchase, is also included in the probit along with the unit's square footage (SIZE) and FLOOR_LEVEL (divided by 100). Unit-level control variables for financing constraints include a PUBLIC_HOUSING indicator variable that equals 1 if the unit's buyer was a resident of public housing at the time of its purchase, and PAID-IN EQUITY, which is defined as the sum of a unit's estimated down payment and cumulative principal repayments normalized by its market price at the quarter-end. FREEHOLD is a dummy variable that equals 1 when a condominium project's lease period is either perpetual or $800+$ years. Market-level financing constraints include the prevailing 3 -month interbank offer rate in Singapore (SIBOR), which monthly mortgage payments are based on and DOWN PAYMENT, the prevailing minimum required percentage down payment. Standard errors are clustered by calendar quarter and $z$-statistics ( $t$-statistics for OLS models) are reported in parentheses. Models 5 and 10 are estimated using OLS with calendar quarter fixed effects and condominium project fixed effects. * **, and *** represent statistical significance at the $10 \%$, $5 \%$, and $1 \%$ levels, respectively.

\section{Panel A. Medium-Term Holding Period}

Medium Holding Period

DUMMY(RETURN>0)

RETURN $^{+}$

$\frac{1}{1.764^{* \star \star}}$

1.764
$(11.31)$

RETURN $^{-}$

HOLDING_PERIOD

LOG(SIZE)

FLOOR_LEVEL

PUBLIC_HOUSING

PAID-IN_EQUITY

FREEHOLD

\begin{tabular}{|c|c|c|}
\hline 3 & 4 & 5 \\
\hline \multirow[t]{3}{*}{$\begin{array}{l}1.318^{* * *} \\
(5.93)\end{array}$} & $\begin{array}{l}0.878^{* * *} \\
(5.63)\end{array}$ & $\begin{array}{l}0.358^{* * *} \\
(4.21)\end{array}$ \\
\hline & $\begin{array}{c}0.169 \\
(0.43)\end{array}$ & $\begin{array}{l}-0.840^{\star *} \\
(-2.02)\end{array}$ \\
\hline & $\begin{array}{l}4.447^{\star \star *} \\
(4.12)\end{array}$ & $\begin{array}{c}0.487 \\
(0.92)\end{array}$ \\
\hline $\begin{array}{l}-0.182^{*} \\
(-1.86)\end{array}$ & 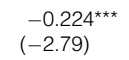 & $\begin{array}{l}-0.137^{\star \star} \\
(-2.35)\end{array}$ \\
\hline $\begin{array}{l}-0.795^{\star \star \star} \\
(-14.34)\end{array}$ & $\begin{array}{c}-0.734^{\star * *} \\
(-12.09)\end{array}$ & $\begin{array}{l}-0.769^{\star \star \star} \\
(-7.72)\end{array}$ \\
\hline $\begin{array}{l}0.894^{* \star *} \\
(3.16)\end{array}$ & $\begin{array}{l}0.734^{* *} \\
(2.42)\end{array}$ & $\begin{array}{l}1.105^{\star \star} \\
(2.47)\end{array}$ \\
\hline 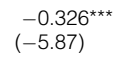 & $\begin{array}{l}-0.351^{\star * *} \\
(-6.20)\end{array}$ & $\begin{array}{l}-0.203^{\star \star \star} \\
(-4.05)\end{array}$ \\
\hline $\begin{array}{l}-2.346^{*} \\
(-1.74)\end{array}$ & $\begin{array}{c}0.668 \\
(0.27)\end{array}$ & $\begin{array}{l}-3.152^{\star \star \star} \\
(-3.55)\end{array}$ \\
\hline
\end{tabular}

Medium Holding Period, Absolute Return Within 20\%

\begin{tabular}{|c|c|c|c|c|}
\hline 1 & 2 & 3 & 4 & 5 \\
\hline \multirow[t]{9}{*}{$\begin{array}{l}1.232^{\star \star \star} \\
(7.00)\end{array}$} & $\begin{array}{l}-0.028 \\
(-0.27)\end{array}$ & $\begin{array}{l}0.943^{* * *} \\
(4.67)\end{array}$ & $\begin{array}{l}-0.035 \\
(-0.37)\end{array}$ & $\begin{array}{l}-0.095 \\
(-0.99)\end{array}$ \\
\hline & $\begin{array}{l}6.092^{\star \star *} \\
(8.44)\end{array}$ & & $\begin{array}{l}5.327^{\star \star \star} \\
(5.11)\end{array}$ & $\begin{array}{l}3.540^{* * *} \\
(3.47)\end{array}$ \\
\hline & $\begin{array}{l}5.623^{* * *} \\
(7.17)\end{array}$ & & 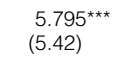 & $\begin{array}{l}1.856^{\star * *} \\
(3.14)\end{array}$ \\
\hline & & $\begin{array}{l}-0.068 \\
(-0.52)\end{array}$ & $\begin{array}{l}-0.170 \\
(-1.46)\end{array}$ & $\begin{array}{l}0.098^{*} \\
(1.88)\end{array}$ \\
\hline & & $\begin{array}{l}-0.415^{\star \star *} \\
(-5.48)\end{array}$ & $\begin{array}{l}-0.283^{\text {** }} \\
(-3.35)\end{array}$ & $\begin{array}{l}-0.622^{* \star *} \\
(-3.62)\end{array}$ \\
\hline & & $\begin{array}{l}0.932^{* *} \\
(2.56)\end{array}$ & $\begin{array}{c}0.323 \\
(0.89)\end{array}$ & $\begin{array}{c}0.455 \\
(1.03)\end{array}$ \\
\hline & & $\begin{array}{l}-0.509^{\star \star \star} \\
(-7.41)\end{array}$ & 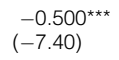 & $\begin{array}{l}-0.371^{\text {***}} \\
(-6.19)\end{array}$ \\
\hline & & $\begin{array}{l}-1.658 \\
(-1.08)\end{array}$ & $\begin{array}{c}2.582 \\
(1.30)\end{array}$ & $\begin{array}{l}-2.263^{\text {** }} \\
(-2.20)\end{array}$ \\
\hline & & $\begin{array}{l}0.226^{\text {*** }} \\
(4.17)\end{array}$ & $\begin{array}{l}0.191^{\text {** }} \\
(3.60)\end{array}$ & \\
\hline
\end{tabular}

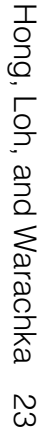


TABLE 5 (continued)

Unit-Level Sell Propensities for Medium and Long Holding Periods

\begin{tabular}{|c|c|c|c|c|c|}
\hline \multicolumn{6}{|c|}{ Panel A. Medium-Term Holding Period (continued) } \\
\hline & \multicolumn{5}{|c|}{ Medium Holding Period } \\
\hline & 1 & 2 & 3 & 4 & 5 \\
\hline Lag(SIBOR) & & & $\begin{array}{l}0.297^{\star \star *} \\
(2.59)\end{array}$ & $\begin{array}{l}0.322^{\star \star *} \\
(2.58)\end{array}$ & \\
\hline DOWN_PAYMENT & & & $\begin{array}{l}-5.474^{* *} \\
(-2.17)\end{array}$ & $\begin{array}{l}-8.307^{\star \star \star *} \\
(-3.09)\end{array}$ & \\
\hline $\begin{array}{l}\text { No. of obs. } \\
\text { Pseudo or Adj. } R^{2} \\
\text { Estimation } \\
\text { Quarter fixed effects } \\
\text { Condo project fixed effects }\end{array}$ & $\begin{array}{c}859,114 \\
0.0200 \\
\text { Probit } \\
\text { No } \\
\text { No }\end{array}$ & $\begin{array}{l}859,114 \\
0.0218 \\
\text { Probit } \\
\text { No } \\
\text { No }\end{array}$ & $\begin{array}{l}834,157 \\
0.0278 \\
\text { Probit } \\
\text { No } \\
\text { No }\end{array}$ & $\begin{array}{l}834,157 \\
0.0290 \\
\text { Probit } \\
\text { No } \\
\text { No }\end{array}$ & $\begin{array}{l}834,156 \\
0.0119 \\
\text { OLS } \\
\text { Yes } \\
\text { Yes }\end{array}$ \\
\hline \multicolumn{6}{|c|}{ Panel B. Long-Term Holding Period } \\
\hline & \multicolumn{5}{|c|}{ Long Holding Period } \\
\hline & 1 & 2 & 3 & 4 & 5 \\
\hline DUMMY(RETURN>0) & $\begin{array}{l}0.867^{\star \star \star} \\
(7.92)\end{array}$ & $\begin{array}{l}0.624^{\star \star \star} \\
(3.86)\end{array}$ & $\begin{array}{l}1.241^{\star \star \star} \\
(8.74)\end{array}$ & $\begin{array}{l}0.773^{\star \star \star} \\
(6.32)\end{array}$ & $\begin{array}{l}0.610^{\star \star \star} \\
(4.36)\end{array}$ \\
\hline RETURN $^{+}$ & & $\begin{array}{l}-0.636^{\star \star \star} \\
(-4.62)\end{array}$ & & $\begin{array}{c}0.163 \\
(0.74)\end{array}$ & $\begin{array}{l}-0.677^{\star *} \\
(-2.39)\end{array}$ \\
\hline RETURN $^{-}$ & & $\begin{array}{l}2.460^{\star \star \star} \\
(4.11)\end{array}$ & & 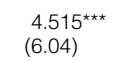 & $\begin{array}{c}0.911^{*} \\
(1.82)\end{array}$ \\
\hline HOLDING_PERIOD & & & $\begin{array}{c}0.013 \\
(0.51)\end{array}$ & $\begin{array}{l}-0.076^{\star \star \star} \\
(-3.34)\end{array}$ & $\begin{array}{l}-0.002 \\
(-0.12)\end{array}$ \\
\hline LOG(SIZE) & & & $\begin{array}{l}-0.435^{\star \star \star} \\
(-4.74)\end{array}$ & $\begin{array}{l}-0.280^{\star \star \star} \\
(-3.09)\end{array}$ & $\begin{array}{l}-0.465^{\star * *} \\
(-4.62)\end{array}$ \\
\hline FLOOR_LEVEL & & & $\begin{array}{l}-0.538^{\star \star} \\
(-2.11)\end{array}$ & $\begin{array}{l}-0.795^{\star \star \star} \\
(-3.73)\end{array}$ & $\begin{array}{l}0.495^{\star \star} \\
(2.29)\end{array}$ \\
\hline PUBLIC_HOUSING & & & $\begin{array}{l}-0.164^{\star \star \star} \\
(-4.60)\end{array}$ & $\begin{array}{l}-0.185^{\star \star \star} \\
(-6.01)\end{array}$ & $\begin{array}{l}-0.121^{\star \star \star} \\
(-4.28)\end{array}$ \\
\hline
\end{tabular}

Medium Holding Period, Absolute Return Within 20\%

\begin{tabular}{|c|c|c|c|c|}
\hline 1 & 2 & 3 & 4 & 5 \\
\hline & & $\begin{array}{l}0.202^{\star \star} \\
(2.07)\end{array}$ & $\begin{array}{l}0.258^{\star \star \star} \\
(2.84)\end{array}$ & \\
\hline & & $\begin{array}{l}-6.040^{\star *} \\
(-2.40)\end{array}$ & $\begin{array}{l}-10.434^{\star \star \star} \\
(-4.17)\end{array}$ & \\
\hline 372,836 & 372,836 & 361,201 & 361,201 & 361,182 \\
\hline 0.0113 & 0.0157 & 0.0226 & 0.0260 & 0.0124 \\
\hline Probit & Probit & Probit & Probit & OLS \\
\hline No & No & No & No & Yes \\
\hline No & No & No & No & Yes \\
\hline
\end{tabular}

Long Holding Period, Absolute Return Within 20\%

\begin{tabular}{|c|c|c|c|c|}
\hline 1 & 2 & 3 & 4 & 5 \\
\hline \multirow[t]{7}{*}{$\begin{array}{l}0.780^{\star \star \star} \\
(6.99)\end{array}$} & $\begin{array}{c}0.170 \\
(1.46)\end{array}$ & $\begin{array}{l}0.897^{\star \star \star \star} \\
(8.82)\end{array}$ & $\begin{array}{c}0.183 \\
(1.62)\end{array}$ & $\begin{array}{c}0.181 \\
(1.48)\end{array}$ \\
\hline & $\begin{array}{c}0.038 \\
(0.06)\end{array}$ & & $\begin{array}{l}2.650^{* \star \star} \\
(2.65)\end{array}$ & $\begin{array}{l}-1.202 \\
(-1.55)\end{array}$ \\
\hline & $\begin{array}{l}5.915^{\star \star \star} \\
(6.76)\end{array}$ & & $\begin{array}{l}8.006^{\star \star \star} \\
(6.31)\end{array}$ & $\begin{array}{r}1.127 \\
(1.49)\end{array}$ \\
\hline & & $\begin{array}{c}0.067 \\
(1.24)\end{array}$ & $\begin{array}{l}-0.074 \\
(-1.11)\end{array}$ & $\begin{array}{c}0.022 \\
(0.95)\end{array}$ \\
\hline & & $\begin{array}{l}-0.262^{*} \\
(-1.84)\end{array}$ & $\begin{array}{l}-0.053 \\
(-0.40)\end{array}$ & $\begin{array}{l}-0.756^{\text {** }} \\
(-3.64)\end{array}$ \\
\hline & & $\begin{array}{l}-0.644 \\
(-1.62)\end{array}$ & $\begin{array}{l}-1.284^{\star \star \star} \\
(-3.02)\end{array}$ & $\begin{array}{l}1.404^{* * *} \\
(3.01)\end{array}$ \\
\hline & & $\begin{array}{l}-0.261^{\star \star \star} \\
(-4.89)\end{array}$ & $\begin{array}{l}-0.267^{\star \star \star} \\
(-5.12)\end{array}$ & $\begin{array}{l}-0.191^{\text {*** }} \\
(-3.38)\end{array}$ \\
\hline
\end{tabular}

(continued on next page) 
TABLE 5 (continued)

Unit-Level Sell Propensities for Medium and Long Holding Periods

\section{Panel B. Long-Term Holding Period (continued)}

\begin{tabular}{|c|c|c|c|c|c|c|c|c|c|c|}
\hline & \multicolumn{5}{|c|}{ Long Holding Period } & \multicolumn{5}{|c|}{ Long Holding Period, Absolute Return Within 20\% } \\
\hline & 1 & 2 & 3 & 4 & 5 & 1 & 2 & 3 & 4 & 5 \\
\hline PAID-IN_EQUITY & & & $\begin{array}{l}0.828 \\
(1.15)\end{array}$ & $\begin{array}{l}3.956^{\star \star \star} \\
(5.47)\end{array}$ & $\begin{array}{l}-1.062^{* *} \\
(-2.56)\end{array}$ & & & $\begin{array}{c}1.729 \\
(1.10)\end{array}$ & $\begin{array}{l}6.397^{\text {***}} \\
(2.97)\end{array}$ & $\begin{array}{l}-4.288^{\text {** }} \\
(-3.81)\end{array}$ \\
\hline FREEHOLD & & & $\begin{array}{l}-0.281^{\text {** }} \\
(-7.19)\end{array}$ & $\begin{array}{l}-0.315^{\star \star \star} \\
(-7.88)\end{array}$ & & & & $\begin{array}{l}-0.433^{\star \star \star} \\
(-6.30)\end{array}$ & $\begin{array}{l}-0.435^{\text {} * \star} \\
(-6.35)\end{array}$ & \\
\hline Lag(SIBOR) & & & $\begin{array}{l}0.274^{\star \star} \\
(2.11)\end{array}$ & $\begin{array}{c}0.199 \\
(1.56)\end{array}$ & & & & $\begin{array}{c}0.240 \\
(1.42)\end{array}$ & $\begin{array}{c}0.222 \\
(1.41)\end{array}$ & \\
\hline DOWN_PAYMENT & & & $\begin{array}{c}-0.153 \\
(-0.14)\end{array}$ & $\begin{array}{l}-3.067^{\star \star \star} \\
(-4.68)\end{array}$ & & & & $\begin{array}{l}2.039 \\
(0.99)\end{array}$ & $\begin{array}{l}-2.972 \\
(-1.24)\end{array}$ & \\
\hline $\begin{array}{l}\text { No. of obs. } \\
\text { Pseudo or Adj. } R^{2} \\
\text { Estimation } \\
\text { Quarter fixed effects } \\
\text { Condo project fixed effects }\end{array}$ & $\begin{array}{l}1,788,992 \\
0.00592 \\
\text { Probit } \\
\text { No } \\
\text { No } \\
\end{array}$ & $\begin{array}{l}1,788,992 \\
0.00846 \\
\text { Probit } \\
\text { No } \\
\text { No } \\
\end{array}$ & $\begin{array}{l}1,733,357 \\
0.0102 \\
\text { Probit } \\
\text { No } \\
\text { No }\end{array}$ & $\begin{array}{l}1,733,357 \\
0.0125 \\
\text { Probit } \\
\text { No } \\
\text { No } \\
\end{array}$ & $\begin{array}{l}1,733,355 \\
0.00713 \\
\text { OLS } \\
\text { Yes } \\
\text { Yes }\end{array}$ & $\begin{array}{l}541,340 \\
0.00392 \\
\text { Probit } \\
\text { No } \\
\text { No } \\
\end{array}$ & $\begin{array}{l}541,340 \\
0.00540 \\
\text { Probit } \\
\text { No } \\
\text { No } \\
\end{array}$ & $\begin{array}{l}520,945 \\
0.00886 \\
\text { Probit } \\
\text { No } \\
\text { No } \\
\end{array}$ & $\begin{array}{c}520,945 \\
0.0110 \\
\text { Probit } \\
\text { No } \\
\text { No } \\
\end{array}$ & $\begin{array}{l}520,921 \\
0.00904 \\
\text { OLS } \\
\text { Yes } \\
\text { Yes } \\
\end{array}$ \\
\hline
\end{tabular}

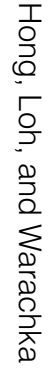




\section{TABLE 6}

\section{Selling Prices for Medium and Long Holding Periods}

Table 6 records the coefficients (in percentages) from an OLS regression whose dependent variable is a unit's selling price premium for units with medium and long holding periods based on quarterly observations from 1998 to 2012. The medium holding period (Panel A) is $>3$ years but not more than 5 years, and the long holding period (Panel $B$ ) is defined as $>5$ years. The selling premium is computed by subtracting 1 from the ratio of a unit's selling price in quarter $t+1$ normalized by its estimated market price. A unit's market price is estimated using the hedonic model in equation (2) provided the adjusted $R^{2}$ in the condominium project exceeds 0.70 . Unit-level capital gains are then estimated by comparing market prices with purchase prices. RETURN_RANK ${ }^{+}$equals $1-5$ for 5 return bins ranging over $(0 \%, 5 \%],(5 \%, 10 \%]$, (10\%, 20\%], (20\%, 30\%], and $>30 \%$, respectively. Similarly, RETURN RANK ${ }^{-}$equals -5 to -1 for 5 return bins ranging over $<-30 \%,[-30 \%,-20 \%),[-20 \%,-10 \%),[-10 \%,-5 \%)$, and $[-5 \%, 0 \%]$, respectively. DUMMY(RETURN $>0$ ) is an indicator variable for units with a capital gain. The unit's HOLDING_PERIOD, defined as the number of years since its purchase, is also included in the probit along with the unit's square footage (SIZE) and FLOOR_LEVEL (divided by 100 ) Unit-level control variables for financing constraints include a PUBLIC HOUSING indicator variable that equals 1 if the unit's buyer was a resident of public housing at the time of its purchase and PAIDIN EQUITY, which is defined as the sum of a unit's estimated down payment and cumulative principal repayments normalized by its market price at the quarter-end. FREEHOLD is a dummy variable that equals 1 when a condominium project's lease period is either perpetual or $800+$ years. Market-level financing constraints include the prevailing 3-month interbank offer rate in Singapore (SIBOR), which monthly mortgage payments are condominium project's lease period is either perpetual or $800+$ years. Market-level financing constraints include the prevailing 3 -month interbank offer rate in Singapore(SIBOR), which monthly mortgage payments are based on, and DOWN_PAYMENT, the prevailing minimum required percentage down payment. Standard errors are clustered by calendar quarter and $t$-statistics are reported in
estimated with calendar quarter fixed effects and condominium project fixed effects. ${ }^{\star \star \star}$, and ${ }^{\star \star \star}$ represent statistical significance at the $10 \%, 5 \%$, and $1 \%$ levels, respectively.

\section{Panel A. Medium-Term Holding Period}

Medium Holding Period, Absolute Return Within $20 \%$

DUMMY(RETURN>0)

RETURN_RANK ${ }^{+}$

RETURN_RANK-

HOLDING_PERIOD

LOG(SIZE)

FLOOR_LEVEL

PUBLIC_HOUSING

PAID-IN_EQUITY

FREEHOLD
Medium Holding Period

\begin{tabular}{|c|c|c|c|c|}
\hline \multicolumn{5}{|c|}{ Medium Holding Period } \\
\hline 1 & 2 & 3 & 4 & 5 \\
\hline \multirow[t]{9}{*}{$\begin{array}{c}-1.391^{\star \star \star} \\
(-10.61)\end{array}$} & $\begin{array}{l}-0.625^{\star \star} \\
(-2.20)\end{array}$ & $\begin{array}{l}-1.336^{\star \star \star} \\
(-6.29)\end{array}$ & $\begin{array}{l}-0.706^{\star \star} \\
(-2.49)\end{array}$ & $\begin{array}{l}-0.695^{\star \star} \\
(-2.08)\end{array}$ \\
\hline & $\begin{array}{l}-0.185^{\star \star \star} \\
(-3.07)\end{array}$ & & $\begin{array}{l}-0.244^{\star \star \star} \\
(-2.89)\end{array}$ & $\begin{array}{l}-0.664^{\star \star \star} \\
(-6.59)\end{array}$ \\
\hline & $\begin{array}{r}0.011 \\
(0.12)\end{array}$ & & $\begin{array}{c}0.012 \\
(0.10)\end{array}$ & $\begin{array}{l}-0.268 \\
(-1.37)\end{array}$ \\
\hline & & $\begin{array}{l}-0.055 \\
(-0.55)\end{array}$ & $\begin{array}{l}0.033 \\
(0.30)\end{array}$ & $\begin{array}{l}-0.013 \\
(-0.09)\end{array}$ \\
\hline & & $\begin{array}{l}-0.625^{\star \star} \\
(-2.01)\end{array}$ & $\begin{array}{l}-0.693^{\star \star} \\
(-2.30)\end{array}$ & 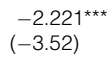 \\
\hline & & $\begin{array}{l}-1.736^{\star \star} \\
(-2.57)\end{array}$ & $\begin{array}{l}-1.687^{\star \star} \\
(-2.55)\end{array}$ & $\begin{array}{l}-1.548 \\
(-1.04)\end{array}$ \\
\hline & & $\begin{array}{l}-0.181 \\
(-1.16)\end{array}$ & $\begin{array}{l}-0.174 \\
(-1.10)\end{array}$ & $\begin{array}{l}-0.130 \\
(-0.88)\end{array}$ \\
\hline & & $\begin{array}{l}3.964^{\star \star} \\
(2.07)\end{array}$ & $\begin{array}{l}0.431 \\
(0.15)\end{array}$ & $\begin{array}{l}-1.521 \\
(-0.35)\end{array}$ \\
\hline & & $\begin{array}{l}0.254^{* *} \\
(2.50)\end{array}$ & $\begin{array}{l}0.232^{\star *} \\
(2.26)\end{array}$ & \\
\hline
\end{tabular}


TABLE 6 (continued)

Selling Prices for Medium and Long Holding Periods

\section{$\underline{\text { Panel A. Medium-Term Holding Period (continued) }}$}

Medium Holding Period

$\operatorname{Lag}(\mathrm{SIBOR})$

DOWN_PAYMENT

No. of obs

Adj. $R^{2}$

Quarter fixed effects

Condo project fixed effects

Predicted Y $(\%)$

Panel B. Long-Term Holding Period

\begin{tabular}{|c|c|c|c|c|}
\hline \multirow[t]{3}{*}{1} & 2 & 3 & 4 & 5 \\
\hline & & $\begin{array}{l}-0.162^{* *} \\
(-2.46)\end{array}$ & 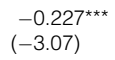 & \\
\hline & & $\begin{array}{l}-6.212^{\star \star} \\
(-2.54)\end{array}$ & $\begin{array}{l}-3.223 \\
(-1.08)\end{array}$ & \\
\hline $\begin{array}{c}17,754 \\
0.00746 \\
\text { No } \\
\text { No } \\
-0.050\end{array}$ & $\begin{array}{c}17,754 \\
0.00816 \\
\text { No } \\
\text { No } \\
-0.050\end{array}$ & $\begin{array}{c}17,262 \\
0.0115 \\
\text { No } \\
\text { No } \\
-0.052\end{array}$ & $\begin{array}{c}17,262 \\
0.0123 \\
\text { No } \\
\text { No } \\
-0.052\end{array}$ & $\begin{array}{c}17,245 \\
0.0183 \\
\text { Yes } \\
\text { Yes } \\
-0.052\end{array}$ \\
\hline
\end{tabular}

Long Holding Period

DUMMY(RETURN>0)

RETURN_RANK ${ }^{+}$

RETURN_RANK ${ }^{-}$

HOLDING_PERIOD

LOG(SIZE)

FLOOR_LEVEL

PUBLIC_HOUSING

PAID-IN_EQUITY

\begin{tabular}{|c|c|c|c|c|}
\hline 1 & 2 & 3 & 4 & 5 \\
\hline \multirow[t]{8}{*}{$\begin{array}{l}-0.700^{\star \star \star} \\
(-9.85)\end{array}$} & $\begin{array}{c}0.145 \\
(0.75)\end{array}$ & $\begin{array}{l}-0.548^{\star \star \star} \\
(-2.78)\end{array}$ & $\begin{array}{c}0.348 \\
(1.54)\end{array}$ & $\begin{array}{l}0.546^{\star \star} \\
(2.34)\end{array}$ \\
\hline & $\begin{array}{l}-0.212^{\star \star \star} \\
(-4.73)\end{array}$ & & $\begin{array}{l}-0.343^{\star \star \star} \\
(-3.89)\end{array}$ & $\begin{array}{l}-0.511^{\star \star \star} \\
(-5.29)\end{array}$ \\
\hline & $\begin{array}{c}0.013 \\
(0.21)\end{array}$ & & $\begin{array}{l}-0.049 \\
(-0.53)\end{array}$ & $\begin{array}{l}-0.239^{\star \star} \\
(-2.13)\end{array}$ \\
\hline & & $\begin{array}{l}-0.075^{\star \star \star} \\
(-3.29)\end{array}$ & $\begin{array}{l}-0.020 \\
(-0.55)\end{array}$ & 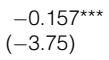 \\
\hline & & $\begin{array}{l}-0.276 \\
(-0.63)\end{array}$ & $\begin{array}{l}-0.359 \\
(-0.86)\end{array}$ & $\begin{array}{l}-1.048 \\
(-1.30)\end{array}$ \\
\hline & & $\begin{array}{l}-1.990^{* *} \\
(-2.24)\end{array}$ & $\begin{array}{l}-1.690^{\star} \\
(-1.92)\end{array}$ & 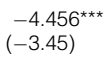 \\
\hline & & $\begin{array}{l}-0.128^{* *} \\
(-2.09)\end{array}$ & $\begin{array}{l}-0.141^{\star \star} \\
(-2.28)\end{array}$ & $\begin{array}{l}-0.070 \\
(-1.03)\end{array}$ \\
\hline & & $\begin{array}{l}1.000 \\
(1.20)\end{array}$ & $\begin{array}{c}-1.904 \\
(-1.32)\end{array}$ & $\begin{array}{l}1.481 \\
(0.98)\end{array}$ \\
\hline
\end{tabular}

Medium Holding Period, Absolute Return Within 20\%

\begin{tabular}{|c|c|c|c|c|}
\hline \multirow[t]{3}{*}{1} & 2 & 3 & 4 & 5 \\
\hline & & $\begin{array}{l}0.000 \\
(0.00)\end{array}$ & $\begin{array}{l}-0.042 \\
(-0.36)\end{array}$ & \\
\hline & & $\begin{array}{l}-8.787^{\star} \\
(-1.70)\end{array}$ & $\begin{array}{l}-5.755 \\
(-0.94)\end{array}$ & \\
\hline 6,305 & 6,305 & 6,126 & 6,126 & 6,014 \\
\hline 0.00796 & 0.00894 & 0.0137 & 0.0148 & 0.0633 \\
\hline No & No & No & No & Yes \\
\hline No & No & No & No & Yes \\
\hline 0.487 & 0.487 & 0.470 & 0.470 & 0.458 \\
\hline
\end{tabular}

Long Holding Period, Absolute Return Within 20\%

\begin{tabular}{|c|c|c|c|c|}
\hline 1 & 2 & 3 & 4 & 5 \\
\hline \multirow[t]{8}{*}{$\begin{array}{l}-0.298^{\star *} \\
(-2.43)\end{array}$} & $\begin{array}{l}-0.171 \\
(-0.72)\end{array}$ & $\begin{array}{l}-0.452^{*} \\
(-1.97)\end{array}$ & $\begin{array}{l}-0.110 \\
(-0.46)\end{array}$ & $\begin{array}{l}-0.091 \\
(-0.37)\end{array}$ \\
\hline & $\begin{array}{l}-0.076 \\
(-0.67)\end{array}$ & & $\begin{array}{l}-0.191 \\
(-1.26)\end{array}$ & $\begin{array}{l}-0.458^{\text {** }} \\
(-2.92)\end{array}$ \\
\hline & $\begin{array}{c}0.039 \\
(0.30)\end{array}$ & & $\begin{array}{l}-0.008 \\
(-0.06)\end{array}$ & $\begin{array}{l}-0.370^{\star * \star} \\
(-2.94)\end{array}$ \\
\hline & & $\begin{array}{l}-0.019 \\
(-0.24)\end{array}$ & $\begin{array}{c}0.015 \\
(0.16)\end{array}$ & $\begin{array}{l}-0.349^{\star \star \star} \\
(-4.40)\end{array}$ \\
\hline & & $\begin{array}{c}0.252 \\
(0.49)\end{array}$ & $\begin{array}{c}0.203 \\
(0.41)\end{array}$ & $\begin{array}{c}0.229 \\
(0.23)\end{array}$ \\
\hline & & $\begin{array}{l}-4.893^{\star \star \star} \\
(-5.25)\end{array}$ & $\begin{array}{l}-4.724^{\star \star \star} \\
(-4.76)\end{array}$ & $\begin{array}{l}-11.460^{\text {** }} \\
(-10.11)\end{array}$ \\
\hline & & $\begin{array}{l}-0.201 \\
(-1.64)\end{array}$ & $\begin{array}{c}-0.199 \\
(-1.64)\end{array}$ & $\begin{array}{l}-0.006 \\
(-0.04)\end{array}$ \\
\hline & & $\begin{array}{l}-2.028 \\
(-0.74)\end{array}$ & $\begin{array}{l}-3.380 \\
(-0.96)\end{array}$ & $\begin{array}{c}0.009 \\
(0.00)\end{array}$ \\
\hline
\end{tabular}

T

ํㅡ

厂

(2)

으

$\sum_{\text {II }}$

อิ 
ABLE 6 (continued)

Selling Prices for Medium and Long Holding Periods

\begin{tabular}{|c|c|c|c|c|c|c|c|c|c|c|}
\hline \multicolumn{11}{|c|}{ Panel B. Long-Term Holding Period (continued) } \\
\hline & \multicolumn{5}{|c|}{ Long Holding Period } & \multicolumn{5}{|c|}{ Long Holding Period, Absolute Return Within 20\% } \\
\hline & 1 & 2 & 3 & 4 & 5 & 1 & 2 & 3 & 4 & 5 \\
\hline FREEHOLD & & & $\begin{array}{l}0.150^{\star \star} \\
(2.20)\end{array}$ & $\begin{array}{l}0.154^{\star \star} \\
(2.26)\end{array}$ & & & & $\begin{array}{l}-0.163 \\
(-1.43)\end{array}$ & $\begin{array}{l}-0.160 \\
(-1.44)\end{array}$ & \\
\hline Lag(SIBOR) & & & 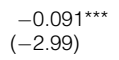 & $\begin{array}{l}-0.135^{\star \star \star} \\
(-3.58)\end{array}$ & & & & $\begin{array}{l}-0.103 \\
(-1.27)\end{array}$ & $\begin{array}{l}-0.107 \\
(-1.32)\end{array}$ & \\
\hline DOWN_PAYMENT & & & $\begin{array}{c}1.752 \\
(1.25)\end{array}$ & $\begin{array}{l}3.784^{* *} \\
(2.11)\end{array}$ & & & & $\begin{array}{l}7.032^{*} \\
(1.90)\end{array}$ & $\begin{array}{l}8.195^{\star} \\
(1.88)\end{array}$ & \\
\hline $\begin{array}{l}\text { No. of obs. } \\
\text { Adj. } R^{2} \\
\text { Quarter fixed effects } \\
\text { Condo project fixed effects } \\
\text { Predicted Y }(\%)\end{array}$ & $\begin{array}{l}32,087 \\
0.00257 \\
\text { No } \\
\text { No } \\
-0.270\end{array}$ & $\begin{array}{l}32,087 \\
0.00373 \\
\text { No } \\
\text { No } \\
-0.270\end{array}$ & $\begin{array}{l}31,091 \\
0.00393 \\
\text { No } \\
\text { No } \\
-0.270\end{array}$ & $\begin{array}{l}31,091 \\
0.00571 \\
\text { No } \\
\text { No } \\
-0.270\end{array}$ & $\begin{array}{l}31,061 \\
0.0104 \\
\text { Yes } \\
\text { Yes } \\
-0.271\end{array}$ & $\begin{array}{l}10,743 \\
0.000459 \\
\text { No } \\
\text { No } \\
0.088\end{array}$ & $\begin{array}{l}10,743 \\
0.000340 \\
\text { No } \\
\text { No } \\
0.088\end{array}$ & $\begin{array}{l}10,392 \\
0.00444 \\
\text { No } \\
\text { No } \\
0.098\end{array}$ & $\begin{array}{l}10,392 \\
0.00454 \\
\text { No } \\
\text { No } \\
0.098\end{array}$ & $\begin{array}{l}10,344 \\
0.0308 \\
\text { Yes } \\
\text { Yes } \\
0.102\end{array}$ \\
\hline
\end{tabular}


TABLE 7

\section{Sell Propensities of Short-Term Units Across Different Return Ranges}

Table 7 records the marginal effects (in percentages) from a probit panel estimation that examines unit-level sell probabilities for units with short holding periods $\leq 3$ years in each quarter of our $1998-2012$ sample. In this analysis, the absolute value of each unit's capital gain is bounded by either $15 \%$ or $25 \%$. The dependent variable equals 1 if a unit is sold in quarter $t+1$ after its capital gain is estimated. RETURN is estimated by subtracting a unit's purchase price from its estimated market price, and then normalizing this difference by the purchase price. A unit's market price is determined using the hedonic model in equation (2) provided the adjusted $R^{2}$ in the condominium project exceeds 0.70 . RETURN $^{+}$is defined as MAX(RETURN, 0 ) and RETURN ${ }^{-}$is defined as MIN(RETURN, 0 ). DUMMY (RETURN>0) is an indicator variable for units with a capital gain. The unit's HOLDING_PERIOD, defined as the number of years since its purchase, is also included in the probit along with the unit's square footage (SIZE) and FLOOR_LEVEL (divided by 100). Unit-level control variables for financing constraints include a PUBLIC_HOUSING indicator variable that equals 1 if the unit's buyer was a resident of public housing at the time of its purchase, and PAID-IN_EQUITY, which is defined as the sum of a unit's estimated down payment and cumulative principal repayments normalized by its market price at the quarter-end. FREEHOLD is a dummy variable that equals 1 when a condominium project's lease period is either perpetual or 800+ years. Market-level financing constraints include the prevaling 3 -month interbank offer rate in Singapore (SIBOR), which monthly mortgage payments are based on, and DOWN_PAYMENT, the prevaling minimum required percentage down payment. Standard errors are clustered by calendar quarter and $z$-statistics ( $t$-statistics for OLS models) are reported in parentheses. Models 5 and 10 are estimated using OLS with calendar quarter fixed effects and condominium project fixed effects. ${ }^{*}{ }^{* *}$, and ${ }^{* \star *}$ represent statistical significance at the $10 \%, 5 \%$, and $1 \%$ levels, respectively.

DUMMY(RETURN>0)

RETURN $^{+}$

RETURN ${ }^{-}$

HOLDING_PERIOD

LOG(SIZE)

FLOOR_LEVEL

PUBLIC_HOUSING

PAID-IN_EQUITY

FREEHOLD

$\operatorname{Lag}(\mathrm{SIBOR})$

DOWN_PAYMENT

No. of obs

Pseudo or Adj. $R^{2}$

Estimation

ondo project fixed effects
Short Holding Period, Absolute Return Within 15\%

\begin{tabular}{|c|c|}
\hline 1 & 2 \\
\hline \multirow[t]{3}{*}{$\begin{array}{l}0.698^{\star \star \star} \\
(9.59)\end{array}$} & $\begin{array}{l}0.093^{*} \\
(1.83)\end{array}$ \\
\hline & $\begin{array}{l}8.164^{\star \star \star} \\
(14.10)\end{array}$ \\
\hline & $\begin{array}{r}-0.110 \\
(-0.12)\end{array}$ \\
\hline
\end{tabular}

\begin{tabular}{|c|c|c|}
\hline 3 & 4 & 5 \\
\hline \multirow[t]{3}{*}{$\begin{array}{l}0.497^{\star \star \star} \\
(8.27)\end{array}$} & $\begin{array}{l}0.110^{\star \star \star} \\
(2.89)\end{array}$ & $\begin{array}{l}-0.019 \\
(-0.39)\end{array}$ \\
\hline & $\begin{array}{l}4.654^{\star \star \star} \\
(8.20)\end{array}$ & $\begin{array}{l}6.921^{\star \star \star} \\
(8.12)\end{array}$ \\
\hline & $\begin{array}{l}2.023^{\star \star \star \star} \\
(2.91)\end{array}$ & $\begin{array}{l}3.084^{\star \star \star \star} \\
(3.04)\end{array}$ \\
\hline $\begin{array}{l}0.570^{\star \star \star} \\
(10.68)\end{array}$ & $\begin{array}{l}0.468^{\star \star \star} \\
(8.72)\end{array}$ & $\begin{array}{l}0.800^{\star \star \star \star} \\
(9.93)\end{array}$ \\
\hline $\begin{array}{l}-0.399^{\star \star \star} \\
(-8.37)\end{array}$ & $\begin{array}{l}-0.348^{\star \star \star} \\
(-7.28)\end{array}$ & $\begin{array}{l}-0.790^{\star \star \star} \\
(-5.71)\end{array}$ \\
\hline $\begin{array}{l}0.401^{\star \star \star} \\
(2.75)\end{array}$ & $\begin{array}{c}0.237^{\star} \\
(1.75)\end{array}$ & $\begin{array}{c}0.310 \\
(1.05)\end{array}$ \\
\hline $\begin{array}{l}-0.232^{\star \star \star} \\
(-8.58)\end{array}$ & $\begin{array}{l}-0.234^{\star \star \star} \\
(-9.02)\end{array}$ & $\begin{array}{l}-0.239^{\star \star \star} \\
(-5.93)\end{array}$ \\
\hline $\begin{array}{l}-2.253^{\star} \\
(-1.70)\end{array}$ & $\begin{array}{c}1.624 \\
(1.09)\end{array}$ & $\begin{array}{l}-2.518^{\star \star} \\
(-2.55)\end{array}$ \\
\hline $\begin{array}{l}0.060^{\star \star \star} \\
(2.81)\end{array}$ & $\begin{array}{l}0.052^{\star \star \star} \\
(2.58)\end{array}$ & \\
\hline $\begin{array}{l}0.010 \\
(0.28)\end{array}$ & $\begin{array}{r}0.032 \\
(0.98)\end{array}$ & \\
\hline $\begin{array}{l}-5.374^{\star \star \star} \\
(-3.73)\end{array}$ & $\begin{array}{l}-8.716^{\star \star \star} \\
(-5.55)\end{array}$ & \\
\hline $\begin{array}{l}1,026,293 \\
0.0693 \\
\text { Probit } \\
\text { No } \\
\text { No }\end{array}$ & $\begin{array}{l}1,026,293 \\
0.0728 \\
\text { Probit } \\
\text { No } \\
\text { No }\end{array}$ & $\begin{array}{l}1,026,291 \\
0.0147 \\
\text { OLS } \\
\text { Yes } \\
\text { Yes }\end{array}$ \\
\hline
\end{tabular}

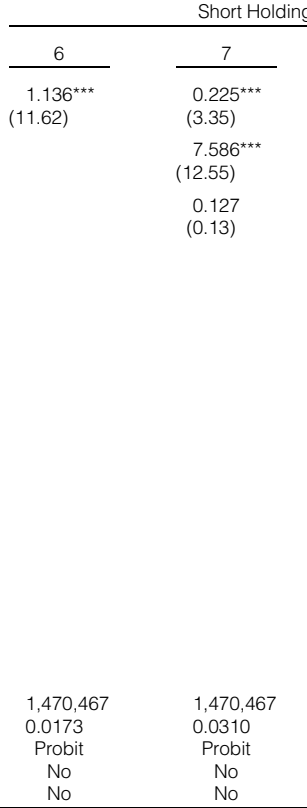

\begin{tabular}{|c|c|}
\hline 9 & 10 \\
\hline $\begin{array}{l}0.232^{\star \star \star} \\
(4.65)\end{array}$ & $\begin{array}{l}-0.100 \\
(-1.48)\end{array}$ \\
\hline $\begin{array}{l}4.540^{\star \star \star} \\
(7.00)\end{array}$ & $\begin{array}{l}7.010^{\star \star \star} \\
(9.21)\end{array}$ \\
\hline $\begin{array}{l}2.690^{\star \star \star} \\
(3.36)\end{array}$ & $\begin{array}{l}3.139^{\star \star \star} \\
(3.32)\end{array}$ \\
\hline $\begin{array}{l}0.466^{\star \star \star} \\
(6.89)\end{array}$ & $\begin{array}{l}0.834^{\star \star \star} \\
(10.25)\end{array}$ \\
\hline $\begin{array}{l}-0.501^{\star \star \star} \\
(-9.07)\end{array}$ & $\begin{array}{l}-1.039^{\star \star \star} \\
(-7.85)\end{array}$ \\
\hline $\begin{array}{l}0.336^{\star \star} \\
(2.10)\end{array}$ & $\begin{array}{c}0.426 \\
(1.51)\end{array}$ \\
\hline $\begin{array}{l}-0.272^{\star \star \star} \\
(-8.58)\end{array}$ & $\begin{array}{l}-0.234^{\star \star \star} \\
(-6.14)\end{array}$ \\
\hline $\begin{array}{l}2.602 \\
(1.38)\end{array}$ & $\begin{array}{l}-3.152^{\star \star \star} \\
(-2.80)\end{array}$ \\
\hline $\begin{array}{l}0.073^{\star \star \star} \\
(3.09)\end{array}$ & \\
\hline $\begin{array}{l}0.073^{\star} \\
(1.65)\end{array}$ & \\
\hline $\begin{array}{l}-10.278^{\star \star \star} \\
(-5.18)\end{array}$ & \\
\hline $\begin{array}{l}1,402,166 \\
0.0715 \\
\text { Probit } \\
\text { No } \\
\text { No }\end{array}$ & $\begin{array}{l}1,402,165 \\
0.0170 \\
\text { OLS } \\
\text { Yes } \\
\text { Yes }\end{array}$ \\
\hline
\end{tabular}

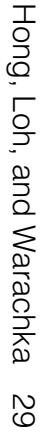


TABLE 8

Selling Prices of Short-Term Units Across Different Return Ranges

Table 8 records the coefficients (in percentages) from an OLS regression whose dependent variable is a unit's selling price premium for units with short holding periods $\leq 3$ years based on quarterly observations from 1998 to 2012 . In this analysis, he absolute value of eachunit's capital gain is bounded by either $15 \%$ or $25 \%$. The selling premium is computed by subtracting 1 from the ratio of a unit's selling price in quarter $t+1$ normalized by its estimated market price. $A$ RETURN is estimated by subtracting a unit's purchase price from its estimated market price, and then normalizing this difference by the purchase price. RETURN RANK+ equals $1-5$ for 5 return bins ranging over ( $0 \%, 5 \%$ ] $(5 \%, 10 \%$ ] $(10 \%, 20 \%],\left(20 \%, 30 \%\right.$, and $>30 \%$, respectively Similarly. RETURN RANK ${ }^{-}$equals -5 to -1 for 5 return bins ranging over $<-30 \%$, $[-30 \%,-20 \%)$, [-20\%, $\left.-10 \%\right)$. [ $\left.-10 \%,-5 \%\right)$, and [ $-5 \%, 0 \%$ ] respectively. DUMMY (RETURN $\left.>0\right)$ is an indicator variable for units with a capital gain. The unit's HOLDING PERIOD, defined as the number of years since its purchase, is also included in the probit along with the unit's square footage (SIZE) and FLOOR LEVEL (divided by 100). Unit-level control variables for financing constraints include a PUBLIC HOUSING indicator variable that equals 1 if the unit's buyer was a resident of public housing at the time of its purchase and PAID-IN EQUITY, which is defined as the sum of a unit's estimated down payment and cumulative principal repayments normalized by its market price at the quarter-end. FREEHOLD is a dummy variable that equals 1 when a condominium project's lease period is either perpetual or $800+$ years. Market-level financing constraints include the prevailing 3-month interbank offer rate in Singapore (SIBOR), which monthly mortgage payments are based on, and DOWN_PAYMENT, the prevailing minimum required percentage down payment. Standard errors are clustered by calendar quarter and $t$-statistics are reported in parentheses. Models 5 and 10 are estimated with calendar quarter fixed effects and condominium project fixed effects. ${ }^{\star},{ }^{\star \star}$, and ${ }^{\star \star \star}$ represent statistical significance at the $10 \%, 5 \%$, and $1 \%$ levels, respectively.

DUMMY (RETURN $>0$ )

RETURN_RANK ${ }^{+}$

RETURN_RANK

HOLDING_PERIOD

LOG(SIZE)

FLOOR_LEVEL

PUBLIC_HOUSING

PAID-IN_EQUITY

FREEHOLD

$\operatorname{Lag}(\mathrm{SIBOR})$

DOWN_PAYMENT

No. of obs.
Pseudo $R^{2}$

Quarter fixed effects

Condo project fixed effects

Predicted $\mathrm{Y}(\%)$
-1.367
$(-6.78)$

$-0.667^{\star \star}$

$(-2.01)$

0.810
$(0.69)$

-0.177
$(-0.95)$

$-0.95$

0.013
$(0.00)$

$-0.511^{\star \star}$

$(-3.69)$

$-0.019$

$-7.412$

$(-1.11)$

0.0380

No

2.067
Short Holding Period, Absolute Return Within 15\%

\begin{tabular}{|c|c|}
\hline 1 & 2 \\
\hline \multirow[t]{3}{*}{$\begin{array}{l}-1.019^{\star \star \star} \\
(-4.47)\end{array}$} & $\begin{array}{l}-0.490 \\
(-1.60)\end{array}$ \\
\hline & $\begin{array}{l}-0.332^{\star \star \star} \\
(-2.71)\end{array}$ \\
\hline & $\begin{array}{c}0.234 \\
(1.07)\end{array}$ \\
\hline
\end{tabular}

$\frac{3}{-1.494^{\star \star \star}}$

\begin{tabular}{|c|c|}
\hline 4 & 5 \\
\hline $\begin{array}{l}-0.450 \\
(-1.45)\end{array}$ & $\begin{array}{l}-0.593^{\star \star} \\
(-2.00)\end{array}$ \\
\hline $\begin{array}{l}-0.588^{\star \star \star} \\
(-4.13)\end{array}$ & $\begin{array}{l}-0.986^{\star \star \star} \\
(-8.66)\end{array}$ \\
\hline $\begin{array}{l}-0.026 \\
(-0.09)\end{array}$ & $\begin{array}{c}-0.371 \\
(-1.44)\end{array}$ \\
\hline $\begin{array}{l}-1.166^{\star \star \star} \\
(-5.23)\end{array}$ & $\begin{array}{l}-0.806^{\star \star \star} \\
(-4.78)\end{array}$ \\
\hline $\begin{array}{l}-0.778^{\star \star} \\
(-2.38)\end{array}$ & $\begin{array}{c}-1.188 \\
(-1.65)\end{array}$ \\
\hline $\begin{array}{c}1.133 \\
(0.98)\end{array}$ & $\begin{array}{l}-3.412^{\star \star} \\
(-2.28)\end{array}$ \\
\hline $\begin{array}{l}-0.163 \\
(-0.85)\end{array}$ & $\begin{array}{c}0.137 \\
(0.82)\end{array}$ \\
\hline $\begin{array}{l}-9.362 \\
(-1.22)\end{array}$ & $\begin{array}{l}-10.262^{\star \star \star} \\
(-4.02)\end{array}$ \\
\hline $\begin{array}{l}-0.496^{\star \star \star} \\
(-3.59)\end{array}$ & \\
\hline $\begin{array}{l}-0.053 \\
(-0.27)\end{array}$ & \\
\hline $\begin{array}{l}1.023 \\
(0.14)\end{array}$ & \\
\hline 11,147 & 11,083 \\
\hline 0.0408 & 0.113 \\
\hline No & Yes \\
\hline No & Yes \\
\hline 2.067 & 2.064 \\
\hline
\end{tabular}

\begin{tabular}{cc}
0.00430 & 0.00542 \\
No & No \\
No & No \\
2.014 & 2.014 \\
\hline
\end{tabular}

\begin{tabular}{|c|c|c|c|c|}
\hline 6 & 7 & 8 & 9 & 10 \\
\hline \multirow[t]{11}{*}{$\begin{array}{l}-1.41{ }^{2 \star \star} \\
(-5.38)\end{array}$} & $\begin{array}{l}-0.125 \\
(-0.50)\end{array}$ & $\begin{array}{l}-1.378^{\star \star \star} \\
(-5.30)\end{array}$ & $\begin{array}{l}-0.142 \\
(-0.57)\end{array}$ & $\begin{array}{l}-0.095 \\
(-0.45)\end{array}$ \\
\hline & $\begin{array}{l}-0.632^{\star \star \star} \\
(-7.46)\end{array}$ & & $\begin{array}{l}-0.741^{\star \star \star} \\
(-7.11)\end{array}$ & $\begin{array}{l}-1.283^{\star \star \star} \\
(-16.25)\end{array}$ \\
\hline & $\begin{array}{l}0.416^{\star \star} \\
(2.44)\end{array}$ & & $\begin{array}{c}0.233 \\
(1.09)\end{array}$ & $\begin{array}{l}-0.355^{\star *} \\
(-2.12)\end{array}$ \\
\hline & & $\begin{array}{l}-1.334^{\star \star \star} \\
(-8.97)\end{array}$ & $\begin{array}{l}-0.985^{\star \star \star} \\
(-5.41)\end{array}$ & $\begin{array}{l}-0.452^{\star \star \star} \\
(-3.23)\end{array}$ \\
\hline & & $\begin{array}{l}-0.629^{*} \\
(-1.86)\end{array}$ & $\begin{array}{l}-0.772^{\star \star} \\
(-2.24)\end{array}$ & $\begin{array}{l}-1.492^{\star} \\
(-1.88)\end{array}$ \\
\hline & & $\begin{array}{l}-0.268 \\
(-0.32)\end{array}$ & $\begin{array}{c}0.202 \\
(0.24)\end{array}$ & $\begin{array}{l}-2.554^{\star \star} \\
(-2.59)\end{array}$ \\
\hline & & $\begin{array}{l}-0.125 \\
(-0.78)\end{array}$ & $\begin{array}{l}-0.081 \\
(-0.49)\end{array}$ & $\begin{array}{c}0.113 \\
(0.74)\end{array}$ \\
\hline & & $\begin{array}{l}13.531^{\star \star} \\
(2.30)\end{array}$ & $\begin{array}{l}-1.256 \\
(-0.19)\end{array}$ & $\begin{array}{l}-11.436^{\star \star \star} \\
(-6.40)\end{array}$ \\
\hline & & $\begin{array}{l}-0.454^{\star \star \star} \\
(-4.03)\end{array}$ & $\begin{array}{l}-0.443^{\star \star \star} \\
(-3.97)\end{array}$ & \\
\hline & & $\begin{array}{l}-0.037 \\
(-0.27)\end{array}$ & $\begin{array}{l}-0.056 \\
(-0.36)\end{array}$ & \\
\hline & & $\begin{array}{l}-17.710^{\star \star \star} \\
(-3.28)\end{array}$ & $\begin{array}{l}-4.988 \\
(-0.83)\end{array}$ & \\
\hline 20,125 & 20,125 & 19,175 & 19,175 & 19,142 \\
\hline 0.00725 & 0.0145 & 0.0285 & 0.0362 & 0.0901 \\
\hline No & No & No & No & Yes \\
\hline No & No & No & No & Yes \\
\hline 1.450 & 1.450 & 1.476 & 1.476 & 1.478 \\
\hline
\end{tabular}


seller. Second, transaction costs are relatively low in the Singapore's residential real estate market, implying the gain threshold that initiates selling is not very different after accounting for transaction costs. Low transaction costs are consistent with the homogeneity and liquidity of Singapore's private residential property market.

In the theoretical literature, models such as Barberis and Xiong (2012) include transaction costs when defining the gain threshold that induces selling. However, empirical studies do not typically incorporate transaction costs when defining gains. For example, Ben-David and Hirshleifer (2012) do not adjust the reference price for transaction costs, nor do Frydman, Hartzmark, and Solomon (2018). While Odean (1998) addresses transaction costs and taxes, he finds these frictions do not alter his conclusions.

Nevertheless, we repeat our main analysis using measures based on transaction-costs adjusted returns. There are 2 types of transaction costs that apply to residential property transactions in Singapore. Sales are assisted by a real estate agent who is affiliated with a real estate brokerage. Almost all transactions are facilitated by a broker due to their low cost. For example, footnote \#1 of Agarwal, He, Sing, and Song (2019) reports that real estate agent commissions are only $1 \%$ for the seller of a residential property in Singapore. Buyers do not pay any agent commissions. The second transaction cost is the buyer stamp duty, which is a tax paid by the buyer. This tax is between $2 \%$ and $3 \%$ depending on the sale price of the property. $^{14}$

Table 9 reports our sell propensity results using transaction-costs adjusted returns. The transaction costs-adjusted return is defined as

(6) ADJ_RETURN $=\frac{(0.99 \times \text { S\$Estimated Price })-(\text { S\$Purchase Price }- \text { S\$Buyer Stamp Duty })}{\text { S\$Purchase Price }}$.

The results in Table 9 are based on returns that are adjusted for transaction costs parallel to those in Table 3. Observe that the coefficients are similar in terms of magnitude and statistical significance. This similarity is not surprising because transaction costs are low and do not vary much across observations. Indeed, unadjusted and adjusted return measures are highly correlated $(>0.90)$ and this multi-collinearity prevents us from including them both in our statistical tests. However, sell propensities around a "zero" capital gain are similar whether capital gains are defined with or without transaction costs.

As both return specifications are statistically indistinguishable due their high correlation, we choose to retain the baseline definition that does not include transaction costs. This choice is motivated by its simpler depiction of investor behavior since the unadjusted purchase price is likely to be a more salient reference price than one complicated by transaction costs. Hartzmark and Solomon (2019) provide a similar example in the stock market as their study of the disposition effect suggests that investors do not adjust reference prices for dividends.

\footnotetext{
${ }^{14}$ The stamp duty payable by the buyer is $1 \%$ for the first $\mathrm{S} \$ 180,000$ of the sale price, $2 \%$ for the next

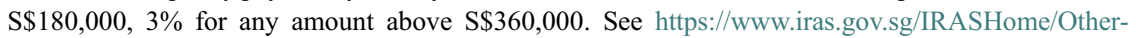
Taxes/Stamp-Duty-for-Property/
} 


\section{TABLE 9}

\section{Unit-Level Sell Propensities for Short Holding Periods with Transaction Costs-Adjusted Returns}

Table 9 records the marginal effects (in percentages) from a probit panel estimation that examines unit-level sell probabilities for units with short holding periods (defined as periods $\leq 3$ years) in each quarter of our 1998-2012 sample. The dependent variable equals 1 if a unit is sold in quarter $t+1$ after its capital gain is estimated. A unit's RETURN is estimated by subtracting its purchase price from its estimated market price, which is determined using the hedonic model in The broker commission is assumed to be $1 \%$ of the unit's market price, which is estimated using the hedonic model in Table 2. The stamp duty payable by the buyer is $1 \%$ for the first $\$ \$ 180,000$ of the sale price, $2 \%$ for the next $\$ \$ 180,000$. $3 \%$ for any amount above $\$ \$ 360,000$. ADJ RETURN ${ }^{+}$is defined as MAX (ADJ RETURN, 0) and ADJ RETURN ${ }^{-}$is defined as MIN(ADJ RETURN 0). DUMMY (ADJ RETURN $>0$ ) is an indicator variable for units with a capital gain. The unit's HOLDING_PERIOD, defined as the number of years since its purchase, is also included in the probit along with the unit's square footage (SIZE) and FLOOR_LEVEL (divided by 100). Unit-level control variables for financing constraints include PUBLIC_HOUSING indicator variable that equals 1 if the unit's buyer was a resident of public housing at the time of its purchase, and PAID-IN_EQUITY, which is defined as the sum of a unit's estimated down payment and cumulative principal repayments normalized by its market price at the quarter-end. FREEHOLD is a dummy variable that equals 1 when a condominium project's lease period is either perpetual or $800+$ years. Market-level financing constraints include the prevailin 3-month interbank offer rate in Singapore (SIBOR), which monthly mortgage payments are based on, and DOWN_PAYMENT, the prevalling minimum required percentage down payment. Standard errors are clustered by calendar quarter and $z$, statistics ( $t$-statistics for $\mathrm{LS}$ models) are reported in parentheses. Models 5 and 10 are estimated using OLS with calendar quarter fixed effects and condominium project fixed effects. ***, and ${ }^{* * *}$ represent statistical significance at the $10 \%, 5 \%$, and $1 \%$ levels, respectively.

Transaction Costs-Adjusted Return

DUMMY(ADJ_RETURN>0)

\begin{tabular}{|c|c|}
\hline 1 & 2 \\
\hline \multirow[t]{3}{*}{$\begin{array}{l}1.837^{\star \star \star} \\
(13.35)\end{array}$} & $\begin{array}{c}1.437^{\star \star \star} \\
(11.68)\end{array}$ \\
\hline & $\begin{array}{l}1.603^{\star \star \star \star} \\
(6.14)\end{array}$ \\
\hline & $\begin{array}{c}0.406 \\
(0.47)\end{array}$ \\
\hline
\end{tabular}

ADJ_RETURN ${ }^{-}$

HOLDING_PERIOD

LOG(SIZE)

FLOOR_LEVEL

PUBLIC_HOUSING

PAID-IN_EQUITY

FREEHOLD

$\operatorname{Lag}(\mathrm{SIBOR})$

DOWN_PAYMENT

No. of obs.

Pseudo or Adj.

Estimation

effects

Condo project fixed effects

\begin{tabular}{|c|c|c|}
\hline & & 5 \\
\hline \multirow{3}{*}{$\begin{array}{c}1.185^{\star \star \star} \\
(10.26)\end{array}$} & $\begin{array}{l}0.963^{\star \star \star} \\
(9.97)\end{array}$ & $\begin{array}{l}0.559^{\star \star \star} \\
(5.60)\end{array}$ \\
\hline & $\begin{array}{l}0.758^{\star} \\
(1.81)\end{array}$ & $\begin{array}{l}0.990^{*} \\
(1.71)\end{array}$ \\
\hline & $\begin{array}{l}3.153^{\star \star \star \star} \\
(3.00)\end{array}$ & $\begin{array}{l}1.675^{\star \star} \\
(2.13)\end{array}$ \\
\hline $\begin{array}{l}0.598^{\star \star \star *} \\
(10.54)\end{array}$ & $\begin{array}{l}0.480^{\star \star \star} \\
(5.20)\end{array}$ & $\begin{array}{l}0.812^{\star \star \star} \\
(9.94)\end{array}$ \\
\hline $\begin{array}{l}-0.731^{\star \star \star} \\
(-12.30)\end{array}$ & $\begin{array}{l}-0.681^{\star \star \star} \\
(-10.81)\end{array}$ & $\begin{array}{l}-1.188^{\star \star \star} \\
(-9.62)\end{array}$ \\
\hline $\begin{array}{l}1.039^{\star \star \star} \\
(3.72)\end{array}$ & $\begin{array}{l}0.817^{\star \star \star \star} \\
(3.76)\end{array}$ & $\begin{array}{l}0.666^{\star \star} \\
(2.52)\end{array}$ \\
\hline $\begin{array}{l}-0.308^{\star \star \star} \\
(-6.63)\end{array}$ & $\begin{array}{l}-0.314^{\star \star \star} \\
(-6.71)\end{array}$ & $\begin{array}{l}-0.213^{\star \star \star} \\
(-5.72)\end{array}$ \\
\hline $\begin{array}{l}-4.113^{\star \star} \\
(-2.26)\end{array}$ & $\begin{array}{c}2.079 \\
(0.81)\end{array}$ & $\begin{array}{l}-5.267^{\star \star \star} \\
(-4.63)\end{array}$ \\
\hline $\begin{array}{l}0.106^{\star \star \star} \\
(3.78)\end{array}$ & $\begin{array}{l}0.106^{\star \star \star} \\
(3.67)\end{array}$ & \\
\hline $\begin{array}{c}0.118 \\
(1.54)\end{array}$ & $\begin{array}{l}0.155^{\star \star} \\
(2.04)\end{array}$ & \\
\hline $\begin{array}{l}-5.731^{\star \star \star} \\
(-3.07)\end{array}$ & $\begin{array}{l}-11.122^{\star \star \star} \\
(-4.25)\end{array}$ & \\
\hline $\begin{array}{l}1,878,999 \\
0.0596 \\
\text { Probit } \\
\text { No } \\
\text { No }\end{array}$ & $\begin{array}{l}1,878,999 \\
0.0605 \\
\text { Probit } \\
\text { No } \\
\text { No }\end{array}$ & $\begin{array}{l}1,878,999 \\
0.0171 \\
\text { OLS } \\
\text { Yes } \\
\text { Yes }\end{array}$ \\
\hline
\end{tabular}

Transaction Costs-Adjusted Absolute Return Within 20\%

\begin{tabular}{|c|c|c|c|c|}
\hline 6 & 7 & 8 & 9 & 10 \\
\hline \multirow[t]{11}{*}{$\begin{array}{l}1.263^{\star \star \star} \\
(14.55)\end{array}$} & $\begin{array}{l}0.372^{\star \star \star} \\
(8.01)\end{array}$ & $\begin{array}{l}0.759^{\star \star \star} \\
(8.46)\end{array}$ & $\begin{array}{l}0.250^{\star \star \star *} \\
(6.37)\end{array}$ & $\begin{array}{l}-0.042 \\
(-0.81)\end{array}$ \\
\hline & $\begin{array}{l}7.770^{\star \star \star} \\
(11.23)\end{array}$ & & $\begin{array}{l}4.352^{\star \star \star \star} \\
(6.67)\end{array}$ & $\begin{array}{l}7.692^{\star \star \star} \\
(9.26)\end{array}$ \\
\hline & $\begin{array}{r}1.220 \\
(1.22)\end{array}$ & & $\begin{array}{l}3.222^{\star \star \star} \\
(3.89)\end{array}$ & $\begin{array}{l}3.021^{\star \star \star} \\
(2.94)\end{array}$ \\
\hline & & $\begin{array}{c}0.653^{\star \star \star} \\
(10.01)\end{array}$ & $\begin{array}{l}0.493^{\star \star \star} \\
(7.02)\end{array}$ & $\begin{array}{l}0.863^{* \star \star} \\
(10.77)\end{array}$ \\
\hline & & $\begin{array}{l}-0.579^{\star \star \star} \\
(-10.88)\end{array}$ & $\begin{array}{l}-0.506^{\star \star \star} \\
(-9.19)\end{array}$ & $\begin{array}{l}-1.054^{\star \star \star} \\
(-7.87)\end{array}$ \\
\hline & & $\begin{array}{l}0.597^{\star \star \star} \\
(3.29)\end{array}$ & $\begin{array}{l}0.362^{\star \star} \\
(2.20)\end{array}$ & $\begin{array}{r}0.437 \\
(1.56)\end{array}$ \\
\hline & & $\begin{array}{l}-0.259^{\star \star \star} \\
(-7.43)\end{array}$ & $\begin{array}{l}-0.272^{\star \star \star} \\
(-8.27)\end{array}$ & $\begin{array}{l}-0.230^{\star \star \star} \\
(-5.77)\end{array}$ \\
\hline & & $\begin{array}{l}-4.342^{\star \star \star} \\
(-2.66)\end{array}$ & $\begin{array}{c}2.079 \\
(1.03)\end{array}$ & $\begin{array}{l}-3.511^{\star \star \star} \\
(-3.14)\end{array}$ \\
\hline & & $\begin{array}{l}0.084^{\star \star \star} \\
(3.15)\end{array}$ & $\begin{array}{l}0.078^{\star \star \star} \\
(3.12)\end{array}$ & \\
\hline & & $\begin{array}{c}0.030 \\
(0.60)\end{array}$ & $\begin{array}{r}0.064 \\
(1.34)\end{array}$ & \\
\hline & & $\begin{array}{l}-4.646^{\star \star \star} \\
(-2.63)\end{array}$ & $\begin{array}{l}-10.106^{\star \star \star} \\
(-4.83)\end{array}$ & \\
\hline 1,349,090 & 1,349,090 & $1,285,168$ & $1,285,668$ & $1,285,167$ \\
\hline 0.0208 & 0.0291 & 0.0685 & 0.0718 & 0.0170 \\
\hline Probit & Probit & Probit & Probit & OLS \\
\hline No & No & No & No & Yes \\
\hline No & No & No & No & Yes \\
\hline
\end{tabular}




\section{F. Stock Transactions}

Our main result from studying real estate data is that sell propensities are flat over losses and increasing in gains. This fits the predictions of realization utility in Barberis and Xiong (2012) with the added assumption of investor heterogeneity. Barberis and Xiong (2012) argue that the salience of reference prices in the housing market makes realization utility applicable, and we find supporting empirical evidence for their argument.

However, the selling propensity pattern we find does not fit recent evidence pertaining to the stock market. For short-term stock transactions, Ben-David and Hirshleifer (2012) show that the sell propensity is V-shaped around a zero capital gain and conclude this evidence supports belief revision. Although the V-shape appears inconsistent with realization utility, Ingersoll and Jin (2013) provide a generalized version of realization utility that has reference-dependent preferences and produces a V-shaped pattern for sell propensities. Intuitively, investors may realize a loss to reset the reference price at a lower level, which provides greater utility if the reinvested proceeds gain in value.

In this section, we replicate Ben-David and Hirshleifer's (2012) methodology to investigate whether some stock transactions exhibit sell propensities similar to the pattern we find for real estate transactions - flat over losses and increasing in gains.

We obtain the discount brokerage data used in Barber and Odean (2000) and carefully replicate Ben-David and Hirshleifer's (2012) main result. ${ }^{15}$ Table 10 reports the results with its legend summarizing how this panel is created. There are 3 sets of results, one for each of the 3 holding periods defined by Ben-David and Hirshleifer (2012): short (1-20 days), medium (21-250 days), and long ( $>250$ days). Since Ben-David and Hirshleifer (2012) find that the V-shaped pattern is strongest over the short horizon, we focus our discussion on the short holding period specifications in models $1-4$.

Table 10 confirms the $\mathrm{V}$-shaped sell propensity for short-term stock investments. According to model 1, the marginal effect of RETURN ${ }^{+}$(variable that equals MAX(RETURN, 0)) on the sell propensity is positive at $3.665 \%$, and the marginal effect of RETURN ${ }^{-}$(variable that equals MIN(RETURN, 0)) on the sell propensity is negative at $-2.340 \% .{ }^{16}$

We then add interactions with a dummy variable LARGE_PURCHASE, which equals 1 for purchases greater than $\$ 20,000$ and 0 otherwise. The estimated marginal effect for the interaction variable LARGE_PURCHASE $\times \mathrm{RETURN}^{+}$in model 2 is insignificantly different from zero, indicating no difference in the sell propensity slope for positive returns. Importantly, the marginal effect for the interaction variable LARGE_PURCHASE $\times \mathrm{RETURN}^{-}$is positive and significant. Its $2.169 \%$ magnitude offsets the negative slope of $-2.428 \%$ for Return ${ }^{-}$. Therefore, the shape of sell propensities for large-sized stock purchases mirror the shape of the sell propensities we estimate for real estate data-flat over losses and

\footnotetext{
${ }^{15}$ We thank Terry Odean for providing these data.

${ }^{16}$ The sign and statistical significance of our marginal effects are very similar to those reported in Ben-David and Hirshleifer (2012). For example, model 1 in our Table 10 mirrors model 1 in Panel A of their Table 4, with almost every sign and statistical significance thresholds matching.
} 


\section{TABLE 10}

\section{Sell Propensities for Stock Transactions}

Table 10 records the marginal effects (in percentages) from a probit panel estimation that examines investor sell probabilities for stocks in holding-period subsamples using the Barber and Odean (2000) discount
brokerage data from Jan. 1990 to Nov. 1996. We report results for 3 holding periods: short (1-20 days), medium (21-250 days), and long (> 250 days). Following Ben-David and Hirshleifer (2012), a large investor-stockday panel is built where an initial core unit is an investor transaction and a random sample of 10,000 investor accounts is used due to computational capacity limitations. An investor-stock-day's cumulative return since purchase is tracked from position opening until the day the position is sold (including a partial sale), or when additional shares of the same stock are purchased, or when the horizon ends. The dependent variable equals 1 for sell days. Return is the cumulative return since purchase computed from CRSP. RETURN ${ }^{+}$is defined as MAX(RETURN, 0) and RETURN ${ }^{-}$is defined as MIN(RETURN, 0 ). The other explanatory variables are: a dummy variable for RETURN=0, a dummy variable for RETURN $>0$, the square root of the number of days the position is held (TIME_OWNED), and the log of the purchase price (BUY_PRICE). Volatility of daily returns is computed for the 1 -year period preceding the purchase and VOLATILITY ${ }^{-}$is equal to this VOLATILITY if the observation is associated with a IOSS (RETURN $\left.\leq 0\right)$, Or is 0 otherwise. VOLATILITY ${ }^{+}$is equal to this VOLATILITY if the observation is a gain (RETURN $>0$ ), or is 0 otherwise. Non-binary variables are winsorized at the extreme $1 \%$. Models 1,5 , and 9 mirror specifications 1,2 , and 3 , respectively, of Panel A in table 4 of Ben-David and If the observation is a gain (RETURN>0), or is 0 otherwise. Non-binary variables are winsorized at the extreme 1\%. Models 1, 5 , and 9 mirror specilications 1,2 , and 3 , respectively, o Panel A in table 4 of Ben-David and Hirshleifer (2012). Three sets of interactions with RETURN and RETURN are examined. A LARGE_PURCHASE dummy is defined as observations associated with purchases with amounts $>\$ 20,000$. A NON_REINVEST dummy is defined as observations not associated with reinvestment. Reinvestment observations are stock-investor observations which when eventually sold are reinvested into another stock on ors are clustered by investor and $z$ statistics are reported in parentheses, with ${ }^{\star},{ }^{\star *}$, and ${ }^{* \star \star}$ representing statistical significance at the $10 \%, 5 \%$, and $1 \%$ levels, respectively.

\begin{tabular}{|c|c|c|c|c|c|c|c|c|c|c|c|c|}
\hline & \multicolumn{4}{|c|}{ Short Horizon (1-20 days) } & \multicolumn{4}{|c|}{ Medium Horizon (21-250 days) } & \multicolumn{4}{|c|}{ Long Horizon (>250 days) } \\
\hline & 1 & 2 & 3 & 4 & 5 & 6 & 7 & 8 & 9 & 10 & 11 & 12 \\
\hline DUMMY(RETURN>0) & $\begin{array}{l}0.222^{\star \star \star} \\
(4.64)\end{array}$ & $\begin{array}{l}0.195^{\star \star \star} \\
(4.18)\end{array}$ & $\begin{array}{l}0.226^{\star \star \star} \\
(4.77)\end{array}$ & $\begin{array}{l}0.217^{\star \star *} \\
(4.58)\end{array}$ & $\begin{array}{l}0.016^{\star} \\
(1.73)\end{array}$ & $\begin{array}{l}0.017^{\star} \\
(1.89)\end{array}$ & $\begin{array}{l}0.021^{\star \star} \\
(2.25)\end{array}$ & $\begin{array}{c}0.015 \\
(1.63)\end{array}$ & $\begin{array}{l}-0.022^{* * \star} \\
(-4.73)\end{array}$ & $\begin{array}{l}-0.021^{\star \star *} \\
(-4.60)\end{array}$ & $\begin{array}{l}-0.018^{\star * *} \\
(-3.96)\end{array}$ & $\begin{array}{l}-0.022^{\star \star \star} \\
(-4.68)\end{array}$ \\
\hline RETURN $^{+}$ & $\begin{array}{l}3.665^{\star \star \star} \\
(23.90)\end{array}$ & $\begin{array}{l}3.554^{\star \star \star} \\
(23.76)\end{array}$ & $\begin{array}{l}2.250^{\star \star \star} \\
(5.98)\end{array}$ & $\begin{array}{l}2.561^{\star * *} \\
(9.54)\end{array}$ & $\begin{array}{c}0.205^{\star \star \star} \\
(17.94)\end{array}$ & $\begin{array}{c}0.216^{\star \star \star} \\
(18.91)\end{array}$ & $\begin{array}{l}0.200^{\star \star \star} \\
(5.74)\end{array}$ & $\begin{array}{l}0.151^{\star \star \star} \\
(7.60)\end{array}$ & $\begin{array}{l}-0.009^{* \star *} \\
(-3.26)\end{array}$ & $\begin{array}{l}-0.007^{\star * *} \\
(-2.73)\end{array}$ & $\begin{array}{c}0.014 \\
(1.61)\end{array}$ & $\begin{array}{l}-0.002 \\
(-0.42)\end{array}$ \\
\hline RETURN $^{-}$ & $\begin{array}{l}-2.340^{\star \star \star} \\
(-11.28)\end{array}$ & $\begin{array}{l}-2.428^{\star \star \star} \\
(-12.18)\end{array}$ & $\begin{array}{l}-1.627^{\star \star \star} \\
(-3.34)\end{array}$ & $\begin{array}{l}-1.866^{\star \star \star} \\
(-5.86)\end{array}$ & $\begin{array}{l}-0.150^{\star \star \star} \\
(-6.31)\end{array}$ & $\begin{array}{l}-0.150^{\star \star \star} \\
(-6.24)\end{array}$ & $\begin{array}{l}-0.267^{\star \star \star} \\
(-5.12)\end{array}$ & $\begin{array}{l}-0.175^{\star \star \star} \\
(-5.07)\end{array}$ & 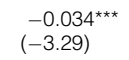 & $\begin{array}{l}-0.032^{* * *} \\
(-3.10)\end{array}$ & $\begin{array}{l}-0.046^{* *} \\
(-2.28)\end{array}$ & $\begin{array}{l}-0.034^{* *} \\
(-2.32)\end{array}$ \\
\hline DUMMY(RETURN=0) & $\begin{array}{l}-0.106^{\star \star \star} \\
(-2.92)\end{array}$ & $\begin{array}{l}-0.084^{\star \star} \\
(-2.45)\end{array}$ & $\begin{array}{l}-0.106^{\star \star \star} \\
(-2.97)\end{array}$ & 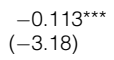 & $\begin{array}{l}-0.081^{\star \star \star} \\
(-4.46)\end{array}$ & $\begin{array}{l}-0.079^{\star \star \star \star} \\
(-4.39)\end{array}$ & $\begin{array}{l}-0.079^{\star \star \star} \\
(-4.45)\end{array}$ & $\begin{array}{l}-0.081^{\star \star \star} \\
(-4.49)\end{array}$ & $\begin{array}{l}-0.005 \\
(-0.17)\end{array}$ & $\begin{array}{l}-0.004 \\
(-0.16)\end{array}$ & $\begin{array}{l}-0.003 \\
(-0.11)\end{array}$ & $\begin{array}{l}-0.004 \\
(-0.16)\end{array}$ \\
\hline SQRT(TIME_OWNED) & $\begin{array}{l}-0.302^{\star \star \star} \\
(-9.58)\end{array}$ & $\begin{array}{l}-0.275^{\star \star \star} \\
(-9.06)\end{array}$ & $\begin{array}{l}-0.296^{\star \star \star} \\
(-9.58)\end{array}$ & 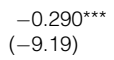 & $\begin{array}{l}-0.029^{\star \star \star} \\
(-30.43)\end{array}$ & $\begin{array}{l}-0.028^{\star \star \star} \\
(-30.16)\end{array}$ & $\begin{array}{l}-0.029^{\star \star \star} \\
(-30.16)\end{array}$ & $\begin{array}{l}-0.029^{\star \star \star} \\
(-30.50)\end{array}$ & $\begin{array}{l}-0.006^{\star \star \star} \\
(-24.61)\end{array}$ & $\begin{array}{l}-0.006^{\star \star *} \\
(-24.49)\end{array}$ & $\begin{array}{l}-0.006^{\star \star *} \\
(-23.53)\end{array}$ & $\begin{array}{l}-0.006^{* * *} \\
(-24.64)\end{array}$ \\
\hline LOG(BUY_PRICE) & $\begin{array}{l}0.165^{\star \star \star} \\
(5.24)\end{array}$ & $\begin{array}{l}0.104^{\star \star \star} \\
(3.69)\end{array}$ & $\begin{array}{l}0.163^{\star \star \star} \\
(5.26)\end{array}$ & $\begin{array}{l}0.166^{\star \star \star} \\
(5.30)\end{array}$ & $\begin{array}{l}0.018^{\star \star \star} \\
(4.34)\end{array}$ & $\begin{array}{l}0.012^{\star \star \star} \\
(2.81)\end{array}$ & $\begin{array}{l}0.019^{\star \star \star} \\
(4.49)\end{array}$ & $\begin{array}{l}0.018^{\star \star \star} \\
(4.38)\end{array}$ & $\begin{array}{c}0.002 \\
(1.32)\end{array}$ & $\begin{array}{l}0.002 \\
(1.05)\end{array}$ & $\begin{array}{c}0.003 \\
(1.47)\end{array}$ & $\begin{array}{l}0.002 \\
(1.29)\end{array}$ \\
\hline VOLATILITY' ${ }^{+}$ & $\begin{array}{l}13.196^{\star \star \star} \\
(9.22)\end{array}$ & $\begin{array}{l}12.523^{\text {***}} \\
(9.48)\end{array}$ & $\begin{array}{l}12.854^{\star \star \star} \\
(9.13)\end{array}$ & $\begin{array}{l}12.697^{\star \star \star} \\
(8.89)\end{array}$ & $\begin{array}{l}5.475^{\star \star \star} \\
(20.44)\end{array}$ & $\begin{array}{l}5.420^{\star \star \star} \\
(20.59)\end{array}$ & $\begin{array}{l}5.382^{\star \star \star} \\
(20.51)\end{array}$ & $\begin{array}{l}5.477^{\star \star \star} \\
(20.41)\end{array}$ & $\begin{array}{l}2.719^{\star \star \star} \\
(16.84)\end{array}$ & $\begin{array}{l}2.711^{\star \star \star} \\
(16.86)\end{array}$ & $\begin{array}{l}2.605^{\star \star \star} \\
(16.76)\end{array}$ & $\begin{array}{l}2.723^{\star \star \star} \\
(16.86)\end{array}$ \\
\hline VOLATILITY' & $\begin{array}{l}13.859^{\star \star \star} \\
(9.22)\end{array}$ & $\begin{array}{l}12.972^{\star \star \star} \\
(9.28)\end{array}$ & $\begin{array}{l}13.676^{\star \star \star} \\
(9.19)\end{array}$ & $\begin{array}{l}13.095^{\star \star \star} \\
(9.12)\end{array}$ & $\begin{array}{l}1.759^{\star \star \star} \\
(6.38)\end{array}$ & $\begin{array}{l}1.762^{\star \star \star} \\
(6.47)\end{array}$ & $\begin{array}{l}1.810^{\star \star \star} \\
(6.66)\end{array}$ & $\begin{array}{l}1.731^{\star \star \star} \\
(6.28)\end{array}$ & $\begin{array}{r}0.141 \\
(0.98)\end{array}$ & $\begin{array}{c}0.161 \\
(1.11)\end{array}$ & $\begin{array}{c}0.192 \\
(1.38)\end{array}$ & $\begin{array}{c}0.152 \\
(1.05)\end{array}$ \\
\hline LARGE_PURCHASE & & $\begin{array}{c}1.532^{\star \star \star} \\
(12.07)\end{array}$ & & & & $\begin{array}{c}0.271^{\star \star \star} \\
(12.91)\end{array}$ & & & & $\begin{array}{l}0.032^{\star \star \star} \\
(3.91)\end{array}$ & & \\
\hline
\end{tabular}


TABLE 10 (continued)

Sell Propensities for Stock Transactions

\begin{tabular}{|c|c|c|c|c|c|c|c|c|c|c|c|c|}
\hline & \multicolumn{4}{|c|}{ Short Horizon ( $1-20$ days) } & \multicolumn{4}{|c|}{ Medium Horizon (21-250 days) } & \multicolumn{4}{|c|}{ Long Horizon (>250 days) } \\
\hline & 1 & 2 & 3 & 4 & 5 & 6 & 7 & 8 & 9 & 10 & 11 & 12 \\
\hline $\begin{array}{l}\text { LARGE_PURCHASE } \times \\
\text { RETURN }^{+}\end{array}$ & & $\begin{array}{l}-0.003 \\
(-0.01)\end{array}$ & & & & $\begin{array}{l}-0.158^{\star \star \star} \\
(-3.71)\end{array}$ & & & & $\begin{array}{l}-0.029^{\star \star \star} \\
(-3.07)\end{array}$ & & \\
\hline $\begin{array}{l}\text { LARGE_PURCHASE } \times \\
\text { RETURN }^{-}\end{array}$ & & $\begin{array}{l}2.169^{\star \star \star} \\
(4.12)\end{array}$ & & & & $\begin{array}{l}0.168^{\star \star \star} \\
(2.59)\end{array}$ & & & & $\begin{array}{l}-0.008 \\
(-0.35)\end{array}$ & & \\
\hline NON_REINVEST & & & $\begin{array}{l}-0.902^{\star \star \star} \\
(-14.95)\end{array}$ & & & & $\begin{array}{l}-0.276^{\star \star \star} \\
(-21.30)\end{array}$ & & & & $\begin{array}{l}-0.218^{\star \star \star} \\
(-22.33)\end{array}$ & \\
\hline $\begin{array}{l}\text { NON_REINVEST } \times \\
\text { RETURN }^{+}\end{array}$ & & & $\begin{array}{l}1.505^{\star \star \star} \\
(4.29)\end{array}$ & & & & $\begin{array}{c}0.004 \\
(0.12)\end{array}$ & & & & $\begin{array}{l}-0.022^{\star \star} \\
(-2.54)\end{array}$ & \\
\hline $\begin{array}{l}\text { NON_REINVEST } \times \\
\text { RETURN }^{-}\end{array}$ & & & $\begin{array}{l}-0.778 \\
(-1.64)\end{array}$ & & & & $\begin{array}{l}0.122^{\star \star} \\
(2.42)\end{array}$ & & & & $\begin{array}{r}0.011 \\
(0.59)\end{array}$ & \\
\hline ONE_PURCHASE & & & & $\begin{array}{l}-0.414^{\star \star \star} \\
(-7.32)\end{array}$ & & & & $\begin{array}{l}-0.018^{\star \star} \\
(-2.21)\end{array}$ & & & & $\begin{array}{l}0.008^{* *} \\
(2.12)\end{array}$ \\
\hline $\begin{array}{l}\text { ONE_PURCHASE } \times \\
\text { RETURN }^{+}\end{array}$ & & & & $\begin{array}{l}1.480^{\star \star \star} \\
(5.48)\end{array}$ & & & & $\begin{array}{l}0.069^{\star \star \star} \\
(3.33)\end{array}$ & & & & $\begin{array}{l}-0.008^{*} \\
(-1.69)\end{array}$ \\
\hline $\begin{array}{l}\text { ONE_PURCHASE } \times \\
\text { RETURN }^{-}\end{array}$ & & & & $\begin{array}{l}-0.715^{\star \star} \\
(-2.07)\end{array}$ & & & & $\begin{array}{r}0.031 \\
(0.92)\end{array}$ & & & & $\begin{array}{r}0.001 \\
(0.10)\end{array}$ \\
\hline $\begin{array}{l}\text { No. of obs. } \\
\text { Pseudo } R^{2}\end{array}$ & $\begin{array}{l}1,491,780 \\
0.0354\end{array}$ & $\begin{array}{l}1,491,780 \\
0.0523\end{array}$ & $\begin{array}{l}1,491,780 \\
0.0392\end{array}$ & $\begin{array}{l}1,491,780 \\
0.0382\end{array}$ & $\begin{array}{l}9,101,874 \\
0.0215\end{array}$ & $\begin{array}{l}9,101,874 \\
0.0242\end{array}$ & $\begin{array}{l}9,101,874 \\
0.0247\end{array}$ & $\begin{array}{l}9,101,874 \\
0.0216\end{array}$ & $\begin{array}{l}9,574,185 \\
0.0140\end{array}$ & $\begin{array}{l}9,574,185 \\
0.0143\end{array}$ & $\begin{array}{l}9,574,185 \\
0.0206\end{array}$ & $\begin{array}{l}9,574,185 \\
0.0141\end{array}$ \\
\hline
\end{tabular}


upward sloping over gains. This implies that our results using real estate data differ from Ben-David and Hirshleifer's (2012) because real estate transactions involve large dollar amounts. Indeed, the same sell propensity pattern (flat over losses and upward sloping over gains) is observed for stock transactions involving large dollar amounts.

Table 10 also presents the results for interactions involving nonreinvestment days and single purchases. A reinvestment day is defined according to Frydman et al. (2018) as a day where a sale is accompanied by the purchase of another stock (NON_REINVEST dummy equals 1 if the investor-stock is not associated with reinvestment). The authors argue that when investors sell positions with a large loss and immediately reinvest the proceeds, they retain the same mental account and reference price as the original position. However, Ingersoll and Jin (2013) model investors willing to realize a loss and reinvest the proceeds to reset the reference price at a lower level due to the additional utility from the S-shaped utility function. The model 3 estimations show that the V-shape is present in both reinvestment and noninvestment observations, but the nonreinvestment observations are associated with a significantly steeper positive slope and an insignificantly different negative slope. Since the disposition effect is based on the relative steepness of the positive slope, the latter result is consistent with Frydman et al. (2018) who report the disposition effect is stronger for nonreinvestment observations. The existence of a $\mathrm{V}$-shape in reinvestment observations is consistent with the predictions of Ingersoll and Jin (2013), whereas the V-shape in nonreinvestment observations is more consistent with Ben-David and Hirshleifer's (2012) belief revision. Because there is also a V-shape in nonreinvestment observations, we cannot conclude that the V-shaped pattern in the stock transactions data is driven solely by Ingersoll and Jin's (2013) realization utility.

Table 10 also presents results for single-purchase day interactions. The ONE_PURCHASE dummy equals 1 for investor-stock observations associated with a purchase of a single stock. These purchases are likely associated with more salient reference prices compared to cases where reference prices are weighted averages involving multiple purchases of the same stock. Model 4 of Table 10 shows that single purchases are associated with a more pronounced V-shaped pattern, although the change in the positive slope is larger in magnitude than the change in the negative slope. Therefore, unlike the salience proxy defined by large purchases, using single purchases as a proxy for salience does not lead to sell propensities that are flat over losses and upward sloping in gains. Hence, as shown earlier, the V-shaped pattern is evident for typical short-term stock investments, and any increased saliency associated with single-purchase observations does not induce the same sell propensities as in the real estate market.

In unreported results, probit estimations that use only the subsample of largesized transactions have NON_REINVEST and ONE_PURCHASE interactions that are all statistically insignificant. This highlights the applicability of Barberis and Xiong's (2012) realization utility to large-sized transactions, and indicates that any additional impact provided by the NON_REINVEST and ONE_PURCHASE variables is marginal for large-sized stock transactions.

Barberis and Xiong (2012) argue that the saliency of a transaction is important for realization utility to apply. However, realization utility applying can lead to sell 
propensities that are either flat over losses and upward sloping over gains as Barberis and Xiong (2012) predict, or V-shaped sell propensities as Ingersoll and Jin (2013) predict. Because transaction size appears to have a critical role in differentiating between sell propensities over losses, we examine if the sell propensity slope over losses becomes flatter as the size of a stock transaction increases. Such a pattern could be consistent with investors experiencing more pain admitting mistakes for large purchases compared to small purchases.

We divide stock purchases into 4 groups based either on their size: $\leq \$ 5 \mathrm{k},(\$ 5 \mathrm{k}$, $\$ 10 \mathrm{k}],(\$ 10 \mathrm{k}, \$ 20 \mathrm{k}]$, and $>\$ 20 \mathrm{k}$; or relative size (i.e., size of the position as a fraction of portfolio value): $<0.2,[0.2,0.4),[0.4,0.6)$ and $\geq 0.6$. We repeat the shortterm sell propensity estimations by adding dummy variables for size or relative size and their interactions with RETURN ${ }^{+}$and RETURN ${ }^{-}$. We omit the variables associated with the smallest size group so that this group forms the baseline. Provided it is more painful to admit mistakes for larger purchases, the interaction between size and RETURN ${ }^{-}$should have a more positive marginal effect as size increases. We see in Table 11 that this is indeed the case as the interaction of size with RETURN $^{-}$has an increasingly positive marginal effect as size increases. For relative size, we find a similar pattern. Overall, the larger the size or relative size of a transaction, the flatter the slope of its sell propensity over the loss region.

The results in Table 11 improve our understanding of why real estate transactions produce sell propensities over losses that differ from Ben-David and Hirshleifer (2012). Barberis and Xiong (2012) argue that realization utility applies to salient transactions. The large size of real estate transactions appears to increase salience. Specifically, large investments are more likely to be salient, and hence realization utility is more likely to apply. But different realization utility theories have different sell propensity predictions over the loss region. There are two possible explanations why sell propensities are flat over losses. First, liquidations might occur mostly for exogenous reasons, which is likely for real estate transactions. Second, it might be harder to admit a mistake as the purchase size increases, as indicated by the results in Table 11.

For smaller-sized stock transactions, even for a single purchase, admitting a mistake might be easier. Hence, a V-shaped selling pattern continues to be observed for small stock transactions and we cannot unequivocally distinguish whether Ingersoll and Jin's (2013) version of realization utility or Ben-David and Hirshleifer's (2012) belief revision explanation is responsible for this pattern. However, belief revision cannot explain why large-sized stock transactions and real estate transactions have sell propensities that are flat over losses and upward sloping in gains. Therefore, our main contribution in the article is to show that in these two important settings, sell propensities follow the realization utility predictions of Barberis and Xiong (2012).

\section{Additional Tests and Alternative Explanations}

This section provides empirical results regarding additional tests and alternative explanations. 
TABLE 11

Impact of Stock Transaction Size on Sell Propensities for Short Holding Periods

Table 11 records the marginal effects (in percentages) from a probit panel estimation that examines investor sell probabilities for stocks using the Barber and Odean (2000) discount brokerage data from Jan. 1990 to Nov. 1996. We report results for the short holding periods of 1-20 days. The panel setup and variable definitions are described in the legend of Table 10. Two sets of interactions with size groups are examined, one based on size and another based on relative size. For size, purchases are sorted into size groups $1-4$ based on the dollar value of the purchase in these ranges: $\leq \$ 5 \mathrm{k},(\$ 5 \mathrm{k}, \$ 10 \mathrm{k}],(\$ 10 \mathrm{k}, \$ 20 \mathrm{k}]$, and $>\$ 20 \mathrm{k}$ respectively. For relative size, purchases are sorted into 4 relative size groups $1-4$ based on the value of the stock position as a fraction of portfolio value in these ranges: $<0.2,[0.2,0.4),[0.4,0.6)$, and $\geq 0.6$ respectively. The smallest size or relative size group's variables are excluded from the estimations so that they form the baseline. Standard errors are clustered by investor and $z$-statistics are reported in parentheses, with ${ }^{*},{ }^{\star \star}$, and ${ }^{\star \star \star}$ representing statistical significance at the $10 \%, 5 \%$, and $1 \%$ levels, respectively.

\begin{tabular}{|c|c|c|c|}
\hline & & Four Size C & os Determined By: \\
\hline & Baseline & Dollar Amount of Purchase & Position Relative to Account Value \\
\hline & 1 & 2 & 3 \\
\hline DUMMY(RETURN>0) & $\begin{array}{l}0.222^{* * *} \\
(4.64)\end{array}$ & $\begin{array}{l}0.166^{\star * \star} \\
(3.58)\end{array}$ & $\begin{array}{l}0.218^{\star \star \star} \\
(4.55)\end{array}$ \\
\hline RETURN $^{+}$ & $\begin{array}{c}3.665^{\star \star \star} \\
(23.90)\end{array}$ & $\begin{array}{l}2.947^{\star \star \star} \\
(17.01)\end{array}$ & $\begin{array}{c}3.668^{\star \star \star} \\
(13.19)\end{array}$ \\
\hline RETURN $^{-}$ & $\begin{array}{c}-2.340^{\star \star \star} \\
(-11.28)\end{array}$ & $\begin{array}{l}-2.353^{\star * *} \\
(-9.74)\end{array}$ & $\begin{array}{l}-2.788^{\star \star \star} \\
(-9.91)\end{array}$ \\
\hline DUMMY(RETURN=0) & $\begin{array}{l}-0.106^{* * *} \\
(-2.92)\end{array}$ & $\begin{array}{l}-0.075^{\star *} \\
(-2.25)\end{array}$ & $\begin{array}{l}-0.109^{\star \star \star} \\
(-3.02)\end{array}$ \\
\hline Sqrt (TIME_OWNED) & $\begin{array}{l}-0.302^{* \star \star} \\
(-9.58)\end{array}$ & $\begin{array}{l}-0.266^{\star \star \star} \\
(-9.10)\end{array}$ & $\begin{array}{l}-0.300^{\star \star \star} \\
(-9.57)\end{array}$ \\
\hline LOG (BUY_PRICE) & $\begin{array}{l}0.165^{\star \star \star} \\
(5.24)\end{array}$ & $\begin{array}{l}0.074^{\star *} \\
(2.47)\end{array}$ & $\begin{array}{l}0.155^{\star \star \star} \\
(5.11)\end{array}$ \\
\hline VOLATILITY ${ }^{+}$ & $\begin{array}{l}13.196^{\star \star \star} \\
(9.22)\end{array}$ & $\begin{array}{l}12.905^{\star * *} \\
(9.86)\end{array}$ & $\begin{array}{l}13.093^{\star \star \star} \\
(8.73)\end{array}$ \\
\hline VOLATILITY' & $\begin{array}{l}13.859^{\star \star \star} \\
(9.22)\end{array}$ & $\begin{array}{l}12.825^{\star \star \star} \\
(9.52)\end{array}$ & $\begin{array}{l}13.694^{\star \star \star} \\
(9.11)\end{array}$ \\
\hline SIZE_GROUP_2 & & $\begin{array}{l}0.152^{* *} \\
(2.05)\end{array}$ & $\begin{array}{l}0.100^{*} \\
(1.84)\end{array}$ \\
\hline SIZE_GROUP_2 $\times$ RETURN $^{+}$ & & $\begin{array}{l}1.561^{* * *} \\
(6.45)\end{array}$ & $\begin{array}{l}0.544^{*} \\
(1.86)\end{array}$ \\
\hline SIZE_GROUP_2 $\times$ RETURN ${ }^{-}$ & & $\begin{array}{l}-0.207 \\
(-0.56)\end{array}$ & $\begin{array}{c}0.111 \\
(0.32)\end{array}$ \\
\hline SIZE_GROUP_3 & & $\begin{array}{l}0.640^{* * *} \\
(8.76)\end{array}$ & $\begin{array}{l}0.311^{\star \star \star} \\
(3.63)\end{array}$ \\
\hline SIZE_GROUP_3 $\times$ RETURN ${ }^{+}$ & & $\begin{array}{l}1.230^{* * *} \\
(4.30)\end{array}$ & $\begin{array}{l}-0.324 \\
(-0.89)\end{array}$ \\
\hline SIZE_GROUP_3 $\times$ RETURN $^{-}$ & & $\begin{array}{c}0.526 \\
(1.47)\end{array}$ & $\begin{array}{l}1.063^{\star *} \\
(2.08)\end{array}$ \\
\hline SIZE_GROUP_4 & & $\begin{array}{l}1.884^{\star \star *} \\
(14.00)\end{array}$ & $\begin{array}{c}0.047 \\
(0.57)\end{array}$ \\
\hline SIZE_GROUP_4 $\times$ RETURN $^{+}$ & & $\begin{array}{c}0.426 \\
(1.00)\end{array}$ & $\begin{array}{l}-0.307 \\
(-0.89)\end{array}$ \\
\hline SIZE_GROUP_4 $\times$ RETURN $^{-}$ & & $\begin{array}{l}2.244^{\star \star \star} \\
(4.25)\end{array}$ & $\begin{array}{l}1.114^{\star \star \star} \\
(2.72)\end{array}$ \\
\hline $\begin{array}{l}\text { No. of obs. } \\
\text { Pseudo } R^{2}\end{array}$ & $\begin{array}{l}1,491,780 \\
0.0354\end{array}$ & $\begin{array}{l}1,491,780 \\
0.0592\end{array}$ & $\begin{array}{l}1,491,780 \\
0.0366\end{array}$ \\
\hline
\end{tabular}

\section{A. Adjusting for Inflation}

Our main results assume that investors anchor on the purchase price and their selling decisions depend on this fixed reference price. However, if investors account for inflation, large nominal gains resulting from inflation might provide less utility. To adjust for inflation, we obtain a time-series of the consumer price index from the Singapore Department of Statistics (https://www.singstat.gov.sg/find-data) and 
compute an inflation-adjusted return which equals $\frac{(1+\text { RETURN })}{(1+\pi)}-1$, where RETURN is the cumulative return since purchase from the hedonic model, and $\pi$ is the cumulative inflation since purchase. We reconstruct all our return-based variables using this inflation-adjusted return and re-estimate our main results in Table 3 (sell propensities for short-term units). We find that in this sample, the difference between the average return and the average inflation-adjusted return is $3.5 \%$. This difference is not large due to the short holding period.

The results (unreported) are similar to the original results as the sell propensities remain upward sloping over gains. Specifically, 5 of the 6 marginal effects for RETURN $^{+}$are positive and significant. However, if investors condition on actual returns and not inflation-adjusted returns, then additional noise is introduced into the estimation by conditioning on inflation-adjusted returns.

Overall, we believe that behaviorally biased investors are more likely to anchor on the simple purchase price. A fair amount of sophistication is required to compute an inflation-adjusted purchase price.

\section{B. Belief Revision}

According to Ben-David and Hirshleifer (2012), informed speculative trading provides an alternative explanation for the appearance of the disposition effect. Informed trading can explain the high sell propensities of investors once the price has incorporated their good private information and created a gain. ${ }^{17}$ Informed trading can also explain the delay in selling positions with a loss, and may motivate further purchases at a lower price, provided the arrival of good information is eventually expected to increase the price. Kelly (2018) shows that company insiders must have negative information before they are willing to sell at a loss.

However, unlike the stock market, informed trading in the real estate market is less important since private unit-level information is less relevant to unit-level prices. Instead, the high correlation among unit-level price fluctuations indicates a high sensitivity to market-level price fluctuations. ${ }^{18}$ Therefore, market timing ability rather than selection ability is more important. Consequently, the realization of a loss is more likely to arise from an exogenous liquidity shock than the arrival of negative information. Because we do not find any V-shaped pattern consistent with belief revision in our real estate data, we conclude that realization utility of Barberis and Xiong (2012) offers a better description of selling behavior in this market.

\section{Financing Constraints}

Our results are robust to several proxies for financing constraints at both the investor level (cross section) and the market level (time series). The coefficients for these control variables offer interpretations that are often inconsistent with

\footnotetext{
${ }^{17}$ Crane and Hartzell (2010) examine the property investments of 266 Real Estate Investment Trusts (REITs) and find that REIT managers are subject to the disposition effect. However, their results regarding professional managers in commercial real estate are more difficult to disentangle from informed trading, especially by REIT managers with a broad investment mandate and portfolios containing multiple properties.

${ }^{18}$ For investors with multiple units, portfolio rebalancing is ineffective because of this high crosscorrelation.
} 
financing constraints. Moreover, financing constraints predict the marginal effect of RETURN $^{-}$for sell propensities is positive, but the results in Table 3 report that this marginal effect is not always positive or significant.

The difficulty that financing constraints have in explaining investor behavior is consistent with two perspectives. First, investors may be less financially constrained when purchasing residential properties, especially those investing in relatively less expensive properties. Second, financing constraints may tighten with property price increases due to the high cross correlation between property prices and a higher minimum down payment mandated by the government. Specifically, an increase in equity arising from price appreciation corresponds with the need for a larger down payment as well as a larger loan to purchase an upgrade whose price has also increased.

In unreported results, we test an alternative wealth proxy by including a unit's original purchase price as an independent variable. A higher purchase price is likely associated with greater wealth, and therefore weaker financial constraints. However, adding this control does not alter any of our reported results and its coefficients are generally insignificant.

\section{Mean Reversion}

Another alternative explanation for our results is an expectation of mean reversion in property prices, which might make owners more willing to sell when there is a higher gain. Table 12 reports the autocorrelation in market-level price changes at both an annual and quarterly frequency. These price changes are defined as the percentage change in the market-level PSF over the specific horizon.

At an annual horizon, the autocorrelation in market-level prices is statistically insignificant. At a quarterly horizon, only the first lag is positive as the coefficients are mostly insignificant for additional lags. Thus, market-level price changes in Singapore are not mean reverting. Instead, the positive quarterly autocorrelation

TABLE 12

Autocorrelation in Property Market Returns

Table 12 contains the coefficients from regressing market-level property returns on lagged returns where returns are based on percentage changes in the market-level per square feet (PSF) of condominiums in Singapore every quarter or year. The market-level PSF each period is computed by averaging all transactions within each condominium project during a period, and then averaging these condominium project-level PSF averages. $t$-statistics are in parentheses with *, ${ }_{\star \star *}$, and ${ }^{* \star \star}$ representing the statistical significance of the estimated coefficients at the $10 \%, 5 \%$, and $1 \%$ levels, respectively.

\begin{tabular}{|c|c|c|c|c|c|c|c|c|}
\hline \multirow[b]{2}{*}{ RETURN $t-1$} & \multicolumn{4}{|c|}{ Quarterly Horizon } & \multicolumn{4}{|c|}{ Annual Horizon } \\
\hline & $\begin{array}{l}0.590^{\star \star \star} \\
(6.03)\end{array}$ & $\begin{array}{l}0.714^{\star \star \star} \\
(5.93)\end{array}$ & $\begin{array}{l}0.694^{\star \star \star} \\
(5.61)\end{array}$ & $\begin{array}{l}0.694^{\star \star \star} \\
(5.47)\end{array}$ & $\begin{array}{c}0.160 \\
(0.61)\end{array}$ & $\begin{array}{c}0.208 \\
(0.75)\end{array}$ & $\begin{array}{r}0.251 \\
(1.04)\end{array}$ & $\begin{array}{c}0.454 \\
(1.35)\end{array}$ \\
\hline RETURN $t-2$ & & $\begin{array}{c}-0.209^{\star} \\
(1.74)\end{array}$ & $\begin{array}{c}-0.139 \\
(0.92)\end{array}$ & $\begin{array}{c}-0.135 \\
(0.88)\end{array}$ & & $\begin{array}{c}-0.256 \\
(0.92)\end{array}$ & $\begin{array}{c}-0.250 \\
(1.05)\end{array}$ & $\begin{array}{c}-0.316 \\
(1.18)\end{array}$ \\
\hline RETURN $t-3$ & & & $\begin{array}{c}-0.105 \\
(0.85)\end{array}$ & $\begin{array}{c}-0.115 \\
(0.74)\end{array}$ & & & $\begin{array}{r}0.330 \\
(1.33)\end{array}$ & $\begin{array}{c}0.385 \\
(1.38)\end{array}$ \\
\hline RETURN $t-4$ & & & & $\begin{array}{c}0.013 \\
(0.10)\end{array}$ & & & & $\begin{array}{c}-0.172 \\
(0.59)\end{array}$ \\
\hline INTERCEPT & $\begin{array}{c}0.005 \\
(0.78)\end{array}$ & $\begin{array}{c}0.006 \\
(0.97)\end{array}$ & $\begin{array}{c}0.006 \\
(0.96)\end{array}$ & $\begin{array}{c}0.006 \\
(0.90)\end{array}$ & $\begin{array}{c}0.036 \\
(0.88)\end{array}$ & $\begin{array}{c}0.047 \\
(1.06)\end{array}$ & $\begin{array}{c}0.056 \\
(1.43)\end{array}$ & $\begin{array}{c}0.043 \\
(0.93)\end{array}$ \\
\hline $\begin{array}{l}\text { No. of obs. } \\
\text { Adj. } R^{2}\end{array}$ & $\begin{array}{r}70 \\
0.339\end{array}$ & $\begin{array}{c}69 \\
0.358\end{array}$ & $\begin{array}{c}68 \\
0.358\end{array}$ & $\begin{array}{c}67 \\
0.346\end{array}$ & $\begin{array}{c}16 \\
-0.044\end{array}$ & $\begin{array}{c}15 \\
-0.060\end{array}$ & $\begin{array}{c}14 \\
-0.017\end{array}$ & $\begin{array}{c}13 \\
-0.063\end{array}$ \\
\hline
\end{tabular}


implies that selling a unit with a gain or continuing to hold a unit with a loss are suboptimal decisions.

In summary, while sellers may expect mean reversion in property prices, there is insufficient empirical evidence of mean reversion to justify holding units with a loss or selling units with a gain. Kaustia (2010) also concludes that a belief in mean reversion does not explain the relation between realized returns and trading behavior.

\section{E. Consumption Motive}

The consumption motive underlying property purchases is unlikely to confound our main results that examine units with a short holding period where investment is a more likely motive. Furthermore, the high correlation between unit-level prices in Singapore implies that households are not disadvantaged by selling their unit at a loss when property prices are low in order to purchase a different unit with a similar expected return that better suits their consumption preferences.

Furthermore, unlike the stock market where dividends or partial liquidations can finance consumption, households must sell their unit and "downsize" to convert property gains into consumption. However, these transactions are unlikely to drive our results since the average unit in our sample is relatively small at 1,300 square feet.

\section{Conclusion}

The preference to sell positions with a gain compared to those with a loss is often referred to as the disposition effect. Instead of conditioning exclusively on the difference between gains and losses, realization utility (Barberis and Xiong (2012)) conditions on the magnitude of a seller's gain. Intuitively, realization utility asserts that the larger a gain, the greater the utility associated with its realization. As fewer gains remain unrealized as they increase in magnitude, sell propensities increase with the magnitude of gains.

Using real estate transactions where the return since purchase can be accurately measured, we find that capital gains exert a significant impact on selling decisions. Sellers with a capital gain are more likely to sell their property than those with a capital loss. Consistent with realization utility, sell propensities increase for those with larger capital gains, resulting in sell propensities that are flat over losses and upward sloping over gains. We argue that the large size of real estate investments increases the salience of purchase prices and makes realization utility more applicable. An analysis of a stock brokerage data set provides additional support for realization utility. Specifically, among large-sized stock investment transactions, sell propensities are also flat over losses and increasing in gains.

In summary, our empirical evidence demonstrates that sell propensities are influenced by realization utility. Although data from Singapore's real estate market ensures the accuracy of our return estimates, our results for stock investment transactions suggest that realization utility applies to markets where large transactions involve salient reference prices and distinct mental accounts. 


\section{References}

Agarwal, S.; R. K. Green; E. Rosenblatt; and V. Yao. "Collateral Pledge, Sunk-Cost Fallacy and Mortgage Default." Journal of Financial Intermediation, 24 (2015), 636-652.

Agarwal, S.; J. He; T. F. Sing; and C. Song. "Do Real Estate Agents have Information Advantages in Housing Markets?" Journal of Financial Economics, 134 (2019), 715-735.

Agarwal, S., and W. Qian. "Access to Home Equity and Consumption: Evidence from a Policy Experiment." Review of Economics and Statistics, 99 (2017), 40-52.

Agarwal, S.; S. Rengarajan; T. F. Sing; and Y. Yang. "School Allocation Rules and Housing Prices: A Quasi-Experiment with School Relocation Events in Singapore." Regional Science and Urban Economics, 58 (2016), 42-56.

Barber, B. M.; Y.-T. Lee; Y.-J. Liu; and T. Odean. "Is the Aggregate Investor Reluctant to Realise Losses? Evidence from Taiwan.” European Financial Management, 13 (2007), 423-447.

Barber, B. M., and T. Odean. "Trading Is Hazardous to Your Wealth: The Common Stock Investment Performance of Individual Investors." Journal of Finance, 55 (2000), 773-806.

Barberis, N., and W. Xiong. "What Drives the Disposition Effect? An Analysis of a Long-Standing Preference-Based Explanation." Journal of Finance, 64 (2009), 751-784.

Barberis, N., and W. Xiong. "Realization Utility." Journal of Financial Economics, 104 (2012), 251-271.

Ben-David, I., and D. Hirshleifer. "Are Investors Really Reluctant to Realize Their Losses? Trading Responses to Past Returns and the Disposition Effect." Review of Financial Studies, 25 (2012), $2485-2532$.

Case, K. E.; J. M. Quigley; and R. J. Shiller. "Wealth Effects Revisited 1975-2012." Critical Finance Review, 2 (2013), 101-128.

Cici, G. "The Prevalence of the Disposition Effect in Mutual Funds' Trades." Journal of Financial and Quantitative Analysis, 47 (2012), 795-820.

Crane, A. D., and J. C. Hartzell. "Is There a Disposition Effect in Corporate Investment Decisions? Evidence from Real Estate Investment Trusts.” Working Paper, University of Texas, Austin (2010).

Frydman, C.; N. Barberis; C. F. Camerer; P. L. Bossaerts; and A. Rangel. "Using Neural Data to Test a Theory of Investor Behavior: An Application to Realization Utility." Journal of Finance, 69 (2014), 907-946.

Frydman, C.; S. M. Hartzmark; and D. H. Solomon. "Rolling Mental Accounts." Review of Financial Studies, 31 (2018), 362-397.

Gan, J. "The Real Effects of Asset Market Bubbles: Loan- and Firm-Level Evidence of a Lending Channel." Review of Financial Studies, 20 (2007), 1941-1973.

Gan, J. "Housing Wealth and Consumption Growth: Evidence from a Large Panel of Households." Review of Financial Studies, 23 (2010), 2229-2267.

Genesove, D., and C. Mayer. "Loss Aversion and Seller Behavior: Evidence from the Housing Market." Quarterly Journal of Economics, 116 (2001), 1233-1260.

Genesove, D., and C. J. Mayer. "Equity and Time to Sale in the Real Estate Market." American Economic Review, 87 (1997), 255-269.

Ghysels, E.; A. Plazzi; R. Valkanov; and W. Torous. "Forecasting Real Estate Prices." In Handbook of Economic Forecasting, Vol. 2 of Handbook of Economic Forecasting G. Elliott; C. Granger; and A. Timmermann, eds. Amsterdam: Elsevier (2013).

Giglio, S.; M. Maggiori; and J. Stroebel. "Very Long-Run Discount Rates." Quarterly Journal of Economics, 130 (2015), 1-53.

Gormley, T. A., and D. A. Matsa. "Common Errors: How to (and Not to) Control for Unobserved Heterogeneity." Review of Financial Studies, 27 (2014), 617-661.

Greene, W. H. "The Behavior of the Fixed Effects Estimator in Nonlinear Models." Working Paper, New York University (2002).

Grinblatt, M., and B. Han. "Prospect Theory, Mental Accounting, and Momentum." Journal of Financial Economics, 78 (2005), 311-339.

Han, L. "The Effects of Price Risk on Housing Demand: Empirical Evidence from U.S. Markets." Review of Financial Studies, 23 (2010), 3889-3928.

Han, L. "Understanding the Puzzling Risk-Return Relationship for Housing." Review of Financial Studies, 26 (2013), 877-928.

Hartzmark, S. M., and D. H. Solomon. "The Dividend Disconnect." Journal of Finance, 74 (2019), 2153-2199.

Hayunga, D. K., and H. J. Munneke. "Examining Both Sides of the Transaction: Bargaining in the Housing Market." Real Estate Economics, 47 (2019), 1-29.

Ingersoll, J. E., and L. J. Jin. "Realization Utility with Reference-Dependent Preferences." Review of Financial Studies, 26 (2013), 723-767. 
Kahneman, D., and A. Tversky. "Prospect Theory: An Analysis of Decision Under Risk." Econometrica, 47 (1979), 263-291.

Kaustia, M. "Prospect Theory and the Disposition Effect." Journal of Financial and Quantitative Analysis, 45 (2010), 791-812.

Kelly, P. "The Information Content of Realized Losses.” Review of Financial Studies, 31 (2018), 2468-2498.

O’Connell, P. G. J., and M. Teo. "Institutional Investors, Past Performance, and Dynamic Loss Aversion.” Journal of Financial and Quantitative Analysis, 44 (2009), 155-188.

Odean, T. "Are Investors Reluctant to Realize their Losses?” Journal of Finance, 53 (1998), 1775-1798.

Shefrin, H., and M. Statman. "The Disposition to Sell Winners Too Early and Ride Losers Too Long: Theory and Evidence.” Journal of Finance, 40 (1985), 777-790.

Stein, J. C. "Prices and Trading Volume in the Housing Market: A Model with Down-Payment Effects." Quarterly Journal of Economics, 110 (1995), 379-406.

Vinson, P. "House Prices and Consumption in the United States." Real Estate Economics, 46 (2018), $1-28$.

Weber, M., and C. F. Camerer. "The Disposition Effect in Securities Trading: An Experimental Analysis.” Journal of Economic Behavior and Organization, 33 (1998), 167-184. 